\title{
ASAS HUKUM SEBAGAI PENGOBAT HUKUM; IMPLIKASI PENERAPAN OMNIBUS LAW
}

\author{
BAYU JATI JATMIKA \\ Institut Agama Islam Sultan Muhammad Syafiuddin Sambas
}

\begin{abstract}
Omnibus law adalah undang-undang baru yang memuat beragam substansi aturan yang keberadaannya mengamamdemen beberapa undang-undang sekaligus. Keinginan kuat dari pusat terhadap peningkatan investasi tersebut tidak serta merta diterima oleh daerah, karna dianggap dapat memudarkan nilai kultural masyarakat setempat. Sehingga peran otonomi daerah sangat dominan pada kehendak daerah dalam mengatur daerahnya. Hal tersebut secara perlahan telah diperbaiki melalui Pelayanan Terpadu Satu Pintu, sehingga omnibus law ini mungkin tidak diperlukan untuk menyederhanakan sistem perijinan pusat dan daerah. Omnibus law terkesan otoriter, karna dengan satu UU ini dapat memangkas segala UU yang lain, sementara budaya hukum tiap daerah sangatlah berbeda. Omnibus law ini terdiri dari dua UU besar yaitu UU Cipta Lapangan Kerja dan UU Perpajakan. Jika tujuan utama lahirnya omnibus law ini sebagai penguatan dan perbaikan ekosistem investasi, pada dasarnya yang diperlukan hanyalah pembenahan hukum investasi, hukum dagang dan pembaharuan hukum ekonomi. Dengan demikian langkah yang tepat mungkin dengan pembenahan dan penguatan ekonomi riil, mengatur regulasi persaingan pasar secara sehat tanpa monopoli dan penyederhanaan sistem perpajakan. Resesi dan ketidakpastian ekonomi terjadi karna sistem ekonomi finansial yang sulit untuk diprediksi karna perlambatan ekonomi global. Ditambah lagi dengan revolusi industri 4.0 dengan semakin berkembangnya teknologi yang memberikan kemudahan dalam berbagai transaksi. Namun hal tersebut juga perlu diwaspadai karna semakin maju teknologi maka peradaban manusia akan semakin mundur, karna kemudahan-kemudahan yang diberikan lewat teknologi mempunyai dampak kepada bergesernya nilai-nilai peradaban dalam transaksi ekonomi dan perdagangan.
\end{abstract}

Keywords: Asas Hukum, Sistem Hukum Indonesia, Omnibus Law 


\section{PENDAHULUAN}

Konsep Omnibus Law merupakan konsep hukum yang digunakan di Negara yang menganut sistem Common Law seperti Amerika Serikat dalam membuat aturan atau kebijakan. Aturan dalam konsep ini ialah mendesain satu undang-undang baru untuk mengamandemen beberapa undang-undang sekaligus. Wacana ini terus berkembang karena terlalu banyaknya tumpang tindih regulasi atau peraturan perundang-undangan. Dengan konsep omnibus law ini dianggap sebagai solusi yang tepat saat ini untuk memperbaiki sistem regulasi.

Namun Rancangan Undang-Undang (RUU) omnibus menuai pro dan kontra, karna dianggap tidak sesuai dengan sistem hukum yang berlaku di Indonesia. UU No. 12 Tahun 2011 tentang pembentukan peraturan perundang-undangan tidak mengatur soal aturan omnibus law. Indonesia tidak menganut Undang-Undang Payung karena posisi seluruh undang-undang adalah sama. Undang-undang hasil konsep omnibus law bisa mengarah sebagai UU payung karena mengatur secara menyeluruh yang kemudian mempunyai kekuatan terhadap aturan yang lain. Sehingga beleid omnibus law merupakan aturan yang terkesan dipaksakan oleh pemerintah kepada parlemen. Hal tersebut diperjelas dengan melakukan perubahan UU No. 15 Tahun 2019 tentang perubahan atas UU No 12 Tahun 2011 tentang pembentukan peraturan perundangundangan.

Menurut pakar hukum tata Negara, Jimmy Z. Usfunan, harus dilihat bagaimana isi ketentuan didalam UU payung tersebut, apakah bersifat umum atau detail seperti UU biasa. kalau bersifat umum, maka tidak semua ketentuan yang dicabut melainkan hanya yang bertentangan saja. Tetapi kalau ketentuannya umum, maka akan menjadi soal jika dibenturkan dengan asas Lex Spesialis Degorat Legi Generalis (aturan yang khusus mengesampingkan aturan yang umum). Oleh sebab itu, harus diatur dalam hierarki perundang-undangan perihal kedudukannya agar asas hukumnya menjadi jelas. Asas hukum adalah dasar atau pokok dari sebuah kebenaran yang kemudian digunakan sebagai tumpuan dalam berpikir yang terdapat dalam hukum konkret atau diluar peraturan hukum konkret. 
Asas umum hukum di Indonesia, yang pertama "Lex Posterior Degorat Legi Priori" yakni peraturan perundang-undangan yang baru akan menghapus peraturan yang lama. Yang kedua “Lex Specialis Degorat Lex Generali” yakni peraturan perundang-undangan yang bersifat khusus dapat mengesampingkan peraturan perundang-undangan yang bersifat umum. Yang ketiga "Lex Superior Degorat Legi Inferior" yakni peraturan peundang-undangan yang lebih tinggi mengesampingkan peraturan perundang-undangan yang lebih rendah.

Ketika omnibus law ini diterapkan maka akan menimbulkan masalah/konflik baru karna terjadi nya benturan antar peraturan perundang-undangan, walaupun omnibus law ini me-unifikasi peraturan yang sejenis. Tidak menutup kemungkinan malah akan membuat ketidakpastian hukum, karna asas legalitas semakin tidak jelas karna adanya unifikasi pasal perpasal yang sama secara substansi.

Secara harpiah, definisi omnibus law adalah hukum untuk semua. Istilah ini berasal dari bahasa latin, yakni "omnis" yang berarti segalanya, untuk semua atau banyak. Dengan demikian Omnibus law ini berkaitan atau berurusan dengan berbagai objek atau hal sekaligus, dan memiliki berbagai tujuan. Dapat disimpulkan bahwa omnibus law adalah undang- undang baru yang memuat beragam substansi aturan yang keberadaannya mengamamdemen beberapa undang-undang sekaligus. Tercatat pertama kali undangundang tersebut dibahas pada tahun 1840 di Amerika Serikat. Pada dasarnya omnibus law ini merupakan penyederhanaan dari kendala regulasi yang kerap berbelit-belit dan panjang, dan dapat memperbaiki ekosistem investasi serta daya saing indonesia dalam menghadapi ketidakpastian dan perlambatan ekonomi global.

Keinginan kuat dari pusat terhadap peningkatan investasi tersebut tidak serta merta diterima oleh daerah, karna dianggap dapat memudarkan nilai kultural masyarakat setempat. Sehingga peran otonomi daerah sangat dominan pada kehendak daerah dalam mengatur daerahnya. Hal tersebut secara perlahan telah diperbaiki melalui Pelayanan Terpadu Satu Pintu, sehingga omnibus law ini mungkin tidak diperlukan untuk menyederhanakan sistem perijinan pusat dan daerah. Omnibus law terkesan otoriter, karna dengan satu UU ini dapat memangkas segala UU yang lain, sementara budaya hukum tiap daerah sangatlah berbeda. Omnibus law ini terdiri dari dua UU besar yaitu UU Cipta Lapangan Kerja dan UU Perpajakan. Jika tujuan utama lahirnya omnibus law 
ini sebagai penguatan dan perbaikan ekosistem investasi, pada dasarnya yang diperlukan hanyalah pembenahan hukum investasi, hukum dagang dan pembaharuan hukum ekonomi.

Dengan demikian langkah yang tepat mungkin dengan pembenahan dan penguatan ekonomi riil, mengatur regulasi persaingan pasar secara sehat tanpa monopoli dan penyederhanaan sistem perpajakan. Resesi dan ketidakpastian ekonomi terjadi karna sistem ekonomi finansial yang sulit untuk diprediksi karna perlambatan ekonomi global. Ditambah lagi dengan revolusi industri 4.0 dengan semakin berkembangnya teknologi yang memberikan kemudahan dalam berbagai transaksi. Namun hal tersebut juga perlu diwaspadai karna semakin maju teknologi maka peradaban manusia akan semakin mundur, karna kemudahan-kemudahan yang diberikan lewat teknologi mempunyai dampak kepada bergesernya nilai-nilai peradaban dalam transaksi ekonomi dan perdagangan.

Di era globalisasi banyak memunculkan tatanan dan hubungan antara individu (dalam lapangan hukum perdata) yang di manage oleh peran teknologi, informasi dan komunikasi. Bahkan berbagai bentuk perjanjian yang dulunya dilakukan dengan tatap muka, sekarang telah menggeser manusia untuk tidak lagi bertatapan muka dalam melahirkan sebuah kontrak atau transaksi. Sehingga ruang maya telah menjadi perantara yang lebih cepat melahirkan transaksi melalui elektronik diantara pihak. Dalam pandangan realisme hukum (terutama pemikiran hukum progresif) selalu dicamkan dan dipahami bahwa hukum berjalan tertatih-tatih dibelakang kenyataan (het rech hint ancther). Hal tersebut menyebabkan hukum seharusnya lebih berpacu (berusaha berlari kencang) dalam melakukan penyesuaian dengan perkembangan dan perilaku kehidupan manusia. Tak salah bila hukum dalam lingkaran abad modern selalu dituntut untuk bercermin pada peraturan yang lahir dari kebiasaan manusia tersebut dalam berperilaku. Sebagaimana hukum senantiasa dikatakan juga sebagai perkembangan jiwa suatu bangsa (volkgeist).

Hukum yang dibuat harus sejalan dengan tuntutan masyarakat, kebutuhan yang senyatanya ada dalam kehidupan masyarakat, yang dipandang mendesak untuk diatur ke dalam hukum positif. Hal ini berarti ketika hukum positif ini dapat berlaku secara sosiologis (karena masyarakat memang membutuhkan) dan berlaku secara filosofis 
(karena masyarakat memandang memang hal itu perlu dibuat aturannya). Dengan demikian, menjadi tugas Negara untuk menetapkan pengaturan itu kedalam hukum positif, sehingga peraturan itu berlaku secara yuridis. Hukum positif ketika dibentuk maupun pada saat diterapkan dalam kasus konkret dilapangan, akan bersentuhan dengan faktor ruang dan waktu. Faktor ruang menandakan pada tempat (lokasi) para subjek hukum berada dan berinteraksi dengan sesama dan alam sekitarnya. Faktor waktu menandakan pada kurun masa tertentu pada saat subjek hukum ini hidup dan beraktivitas. Kedua faktor ini membingkai aktivitas manusia sebagai makhluk individu dan sosial, sehingga faktor ruang dan waktu ini dapat membentuk pola perilaku anggota-anggota masyarakat. Adat dan kebiasaan adalah contoh dari pola perilaku orang-orang yang berada dalam ruang yang sama pada kurun waktu tertentu. Kesamaan inilah yang membentuk budaya. Karna itu diperlukan nya proses pembentukan budaya hukum itu terlebih dahulu sebelum menerapkan suatu aturan hukum yang baru. Apalagi dengan hadirnya omnibus law ini secara tidak langsung menyeragamkan hukum menjadi satu, namun tidak semua hukum itu dapat diseragamkan karna setiap daerah pasti mempunyai budaya hukum yang berbeda. Karna jika hanya investasi yang menjadi dasar utama lahirnya omnibus law ini maka hal tersebut pasti akan menuai proses, karna investasi dianggap melunturkan kultur/budaya daerah setempat secara langsung maupun tak langsung. Disitulah timbul berbagai protes ketika muncul atau lahir sebuah aturan baru yang tidak sesuai dengan budaya hukum setempat. Karna itu peran otonomi daerah tersebut menjadi salah satu upaya dalam pembentukan budaya hukum diwilayahnya.

\section{KAJIAN LITERATUR}

\section{Omnibus Law}

Definisi Omnibus Law dimulai kata Omnibus, yakni yang berasal dari bahasa latin dan berarti untuk semuanya. Dalam Black Law Dictionary Ninth Edition Bryan A. Garner menyebutkan bahwa Omnibus ialah relating to or dealing with numero us object or item at once; including many thing or having varius purposes, yang diterjemahan yaitu keterkaitan dengan atau berurusan dengan berbagai objek atau item sekaligus; termasuk banyak hal atau memiliki berbagai tujuan. Bila dipadukan dengan kata Law maka akan bermakna sebagai suatu hokum yang memiliki keterkaitan berbagai objek/ item atau semua hal yang terkait. 
Menurut Pakar Hukum Tata Negara Bivitri Savitri (dalam Wahyudin, 2019) Omnibus Law adalah satu Undang-Undang yang dibuat untuk menyasar isu besar dan mungkin mencabut atau mengubah beberapa Undang-Undang, dengan Undang-Undang ini dimaksudkan untuk merampingkan regulasi dari segi jumlah, selain itu juga untuk menyederhanakan peraturan agar lebih tepat sasaran. Idealnya bukan Cuma penyederhanaan dari segi jumlah, tapi juga dari segi konsistensi dan keterapihan pengaturan.

Tujuan munculnya ide dan gagasan Omnibus Law ini antara lain (a) untuk mengatasi konflik peraturan perundang-undangan secara cepat, efektif, dan efisian; (b) menyeragamkan kebijkan pemerintah baik ditingkat pusat maupun daerah untuk menunjang ik lim investasi; (c) agar pengurusan perizinan lebih terpadu, efisien dn efektif; (d) untuk memutus mata rantai birokrasi administrasi yang berlama-lama dan berbelitbelit; (e) untuk meningkatkan hubungan koordinasi antar instansi terkait karena telah diatur dalam kebijakan omnibus regulation yang terpadu; dan (f) sebagai jaminan adanya kepastian hukum dan perlindungan bagi pengambil kebijakan.

\section{Hukum Investasi}

Investasi adalah penanaman modal untuk satu atau lebih aktiva yang dimiliki biayanya berjangka panjang dengan harapan mendapatkan keuntungan dimasa yang akan dating sebagai kompensasi secara professional atas penundaan konsumsi, dampak inflasi dan risiko yang ditanggung. Keputusan investasi dapat dilakukan individu, dari investasi tersebut yang dapat berupa capital gain/loss dan yield. Investasi dapat dilakukan dalam bentuk investasi pada aspek fisik (real estate) dan investasi pada asset financial (financial asset). Asset fisik adalah asset yang mempunyai wujud fisik secara fisik, sedangkan asset financial adalah surat-surat berharga yang pada umumnya adalah kalim atau aktivariel dari suatu entitas. Dasar hukum investasi di Indonesia diatur dalam peraturan perundangundangan sebagaimana diatur dalam (i) Tap MPR nomor 23/1/1996 dalam pasal 6; (ii) UU nomor 25 tahun 2007; (iii) Asas-asas hukum investasi; dan (iv) Asas Ekonomi.

Asas yang menyatakan bahwa hukum investasi memikili nilai yang bersifat ekonomis antara lain adalah (1) Asas Hukum Internasional, yakni hukum investasi harus memperhatikan nilai-nilai yang berlaku didunia internasional; (2) Asas Dokrasi Ekonomis, yakni penanaman modal dilakukan secara bebas dan terbuka untuk investor 
asing; (3) Asas kemanfaatan, yakni agar penanaman modal ini hasilnya dapat dipergunakan untuk kesejahteraan masyarakat.

\section{Hukum Dagang/Perniagaan}

Hukum dagang timbul karena adanya kaum pedagang, sehingga dibentuklah suatu hukum yang bertujuan untuk mengatur tingkah laku manusia yang turut dalam melakukan perdagangan untuk memperoleh keuntungan. Lebih luas lagi hukum yang mengatur hubungan hukum antara manusia secara individu dan badan-badan hukum satu sama lainnya dalam lapangan perdagangan. Hukum dagang juga dapat disebut hukum perdata khusus bagi kaum pedagang (hukum privat/sipil).

Di Indonesia sendiri pembagian hukum privat (sipil) kedalam Hukum Perdata dan Hukum Dagang sebenarnya bukanlah pembagian yang asas, tetapi pembagian sejarah dari hukum dagang. Bahwa Pembagian tersebut bukan bersifat asasi, yang dapat dilihat sebagaimana yang tercantum dalam pasal 1 KUHD yang menyatakan; "Bahwa peraturan-peraturan KUHS dapat juga dijalankan dalam penyelesaian soal-soal yang disinggung dalan KUHD terkecuali dalam penyelesaian soal-soal yang semata-mata diadakan oleh KUHD itu".

Fakta lain yang membuktikan bahwa pembagian itu bukan pembagian asasi adalah perjanjian jual beli yang merupakan perjanjian terpenting dalam perdagangan tidaklah ditetapkan dalam KUHD dan perjanjian pertanggungan (asuransi) yang sangat penting juga soal keperdataan ditetapkan dalam KUHD.

\section{METODE PENELITIAN}

Penelitian ini menggunakan pendekatan penelitian kualitatif sebagai metode ilmiah yang sering digunakan dan dilaksanakan oleh sekelompok peneliti dalam bidang ilmu social termasuk juga ilmu pendidikan. Penelitian kualitatif dilaksanakan untuk membangun pengetahuan melalui pemahaman dan penemuan. Penelitian kualitatif adalah suatu proses penelitian dan pemahaman yang berdasarkan pada metode yang menyelidiki suatu fenomena social dan masalah manusia. Penelitian kualitatif dilakukan pada kondisi alamiah dan bersifat penemuan. Dalam pene litian kualitatif, peneliti adalah instrument kunci, oleh karena itu peneliti harus memiliki bekal teori dan wawasan yang luas sehingga dapat bertanya, menganalisis dan mengkonstruksi objek yang diteliti 
menjadi lebih jelas dengan tujuan untuk mengkonstruksi logika dan penalaran secara runtut, agar penelitian lebih menekankan pada makna dan terikat nilai.

Metode penelitian kualitatif adalah metode penelitian yang berlandaskan pada filsafat postpositivisme atau paradigma interpretive, suatu realitas atau objek tidak dapat dilihat secara parsial dan dipecahkan kedalam beberapa variabel. Penelitian kualitatif memandang objek sebagai sesuatu yang dinamis, hasil konstruksi pemikiran dan interprestasi terhadap gejala yang diamati, serta utuh (holistik) karena setiap aspek dari objek itu mempunyai satu kesatuan yang tidak dapat dipisahkan. Penelitian kualitatif digunakan untuk meneliti pada kondisi objek alamiah, teknik pengumpulan data dilakukan dengan triangulasi (gabungan), analisis data bersifat induktif/kualitatif.

\section{HASIL PENELITIAN DAN PEMBAHASAN}

Indonesia menganut sistem Eropa Kontinental (Civil Law) yang mempunyai tiga karakteristik yaitu adanya kodifikasi, hakim tidak terkait kepada preseden atau doktrin stare decicis, sehingga undang-undang menjadi sumber hukum yang terutama, dan sistem peradilan bersifat inkuisitorial. Keutamaan dari karakteristik tersebut yang menjadi pokok atau pangkal dari sistem hukum Civil Law ialah hukum memperoleh kekuatan mengikat, karena dimanifestasikan dalam peraturan-peraturan yang berbentuk undang-undang dan tersusun secara sistematik didalam kodifikasi. Karakteristik pokok yang dianut memperhatikan nilai utama yang merupakan tujuan hukum ialah kepastian hukum. Kepastian hukum hanya dapat dimanifestasikan jikalau tindakan-tindakan hukum manusia dalam pergaulan hid up diatur dengan peraturan-peraturan hukum tertulis.

Tujuan hukum tersebut dan berdasarkan sistem hukum yang dianut, hakim tidak dapat leluasa menciptakan hukum yang mempunyai kekuatan mengikat umum. Hakim hanya bertugas menetapkan dan menafsirkan peraturan-peraturan dalam batasan-batasan wewenangnya. Dengan demikian putusan seorang hakim dalam suatu perkara hanya mengikat pihak-pihak yang berperkara saja (Doktrins Res Ajudicata).

Oleh sebab itu, sistem hukum ini tidak dinamis dalam penerapannya (cenderung kaku) karena tugas hakim tidak lebih dari sekedar alat undang-undang. Hakim tak ubahnya sebagai abdi undang-undang yang tidak memiliki kewenangan melakukan penafsiran guna mendapatkan nilai keadilan yang sesungguhnya. Walaupun civil law 
juga menggunakan sistem inkuisitorial dalam peradilan, dimana hakim mempunyai peranan yang besar dalam mengarahkan dan memutuskan perkara, hakim juga aktif dalam menelaah dan menemukan fakta dan cermat serta teliti dalam menilai alat bukti untuk memperoleh gambaran lengkap dari peristiwa yang dihadapinya sejak awal.

Jika diamati dari sistem ketatanegaraan Republik Indonesia (UUD 1945) tidak menganut suatu sistem negara manapun. Karena memiliki suatu sistem khas menurut kepribadian bangsa Indonesia. Sebelum terjadinya amandemen UUD 1945 yang mengatur kedudukan lembaga tertinggi dan lembaga tinggi negara, serta hubungan antar lembaga-lembaga tersebut, UUD 1945 merupakan hukum tertinggi, kemudian kedaulatan rakyat diserahkan seluruhnya kepada MPR (lembaga tertinggi). Penyebab terjadinya amandemen UUD 1945 adalah karena masa orde baru kekuasaan tertinggi ditangan MPR, yang dianggap disalahgunakan, kemudian lakukan perubahan dengan tujuan perubahan UUD 1945 pada waktu itu adalah untuk menyempurnakan aturan dasar seperti tatanan negara, hak asasi manusia, kedaulatan rakyat, dan lain-lain yang sesuai dengan perkembangan aspirasi dan kebutuhan bangsa.

Penyelenggaraan Negara tidak terlepas dari ajaran trias politica Montesquieu yakni pemisahan kekuasaan Negara menjadi tiga yaitu Legislatif, Eksekutif dan Yudikatif yang kemudian masing-masing kekuasaan tersebut dalam pelaksanaannya diserahkan kepada satu badan mandiri. Artinya masing-masing badan badan itu satu sama lain tidak dapat saling mempengaruhi dan tidak dapat saling meminta pertanggungjawaban. Eksekutif yakni kekuasaan untuk menjalankan undang-undang, legislatif yakni kekuasaan untuk membentuk undang-undang, dan yudikatif yakni kekuasaan mengadili terhadap pelanggaran atas undang-undang. Dengan demikian, DPR memiliki kewenangan yang besar, sebagai lembaga tertinggi untuk menjalankan pemerintahan. Ini artinya tidak ada mekanisme check and balance dari parlemen, sehingga DPR bisa berbuat semena-mena dengan membuat UU sesuai kepentingan kelompok atau sesuai pesanan yang mempunyai kepentingan.

Negara Indonesia menganut sistem pemerintahan presidensiil, menurut pakar ilmu politik dunia Rod Hague yang dikutip oleh Prof H. Dede Mariana Guru Besar Fisip Unpad, menyebutkan ada tiga unsur sistem pemerintahan presidensiil, salah satunya tidak ada status yang tumpang tindih antara badan eksekutif dan legislatif. Presiden 
mempunyai kedudukan yang sangat kuat dan dominan di pemerintahan, namun saat ini kekuasaan presiden seolah dipreteli. Proses pembuatan kebijakan lebih didominasi peran DPR, namun DPR nyatanya masih belum bekerja untuk rakyat. Ketidaberdayaan sistem presidensiil dalam menjalankan pemerintahan salah satunya karena ketidakjelasan lembaga legislatif. Karna sistem parlementer juga kuat mempengaruhi sistem presidensiil. Hal ini terjadi setelah MPR diturunkan kedudukannya menjadi lembaga tinggi negara.

Perkembangan hukum serta kebutuhan hukum masyarakat berubah sesuai dengan perkembangan zaman. Oleh sebab itu, seiring dengan berkembangnya zaman peraturan perundang-undangan yang telah dibuat terkadang perlu adanya perbaikan dan penyesuaian agar sesuai dengan kebutuhan hukum masyarakat. Pembentukan peraturan perundang-undangan meliputi kejelasan yang ingin dicapai, kelembagaan yang tepat, kesesuaian isi materi, efektifitas peraturan perundang-undangan, kejelasan dalam perumusan, kemanfaatan untuk mengatur masyarakat, kepastian hukum dan keterbukaan (transparan) dalam pembuatan peraturan perundang-undangan. Hal-hal tersebut merupakan dasar bagi pembentuk peraturan perundang-undangan. Dalam proses pembentukan peraturan perundang-undangan tidak hanya secara asal tanpa mempertimbangkan kemanfaatan bagi masyarakat, namun harus dibuat sedemikian rupa dengan mempertimbangkan asas pembentukan peraturan perundang-undangan dan bertujuan untuk keadilan masyarakat. Pembentukan peraturan perundang-undangan tersebut diatur dalam UU Nomor 10 Tahun 2004 tentang pembentukan peraturan perundang-undangan. Setelah undang-undang tersebut dilaksanakan kurang lebih 7 tahun, terjadi penggantian atau perubahan terhadap pasal-pasal tersebut, dikarenakan masalah hierarki peraturan perundang-undangan.

Kemudian UU No. 10 Tahun 2004 dirubah lagi menjadi UU No. 12 Tahun 2011 tentang pembentukan peraturan perundang-undangan dengan mengatur kembali isi atau materi muatan termasuk hierarki peraturan perundang-undangan yang menjadi masalah dalam perubahan undang-undang tersebut. Dalam pasal 7 ayat (1) UU No. 10 Tahun 2004 sebagaimana disebutkan hierarki peraturan perundang-undangan terdiri dari UUD 1945, Undang-Undang/Peraturan Pemerintah Pengganti Undang-Undang, Peraturan Pemerintah, Peraturan Presiden, dan peraturan daerah. Sedangkan didalam pasal 7 ayat (1) UU Nomor 12 Tahun 2011 terdapat penambahan dengan memasukkan TAP MPR. 
Sebagaimana bunyi pasal 7 ayat (1) UU No. 12 Tahun 2011 yaitu; 1) Undang-Undang Dasar Negara Republik Indonesia Tahun 1945; 2) Ketetapan Majelis Permusyawaratan Rakyat; 3) Undang-Undang/Peraturan Pemerintah Pengganti Undang-Undang; 4) Peraturan Pemerintah; 5) Peraturan Presiden; 6) Peraturan Daerah Provinsi; 7) Peraturan Daerah Kabupaten/Kota. Berikut gambar hierarki peraturan perundang-undangan di Indonesia.

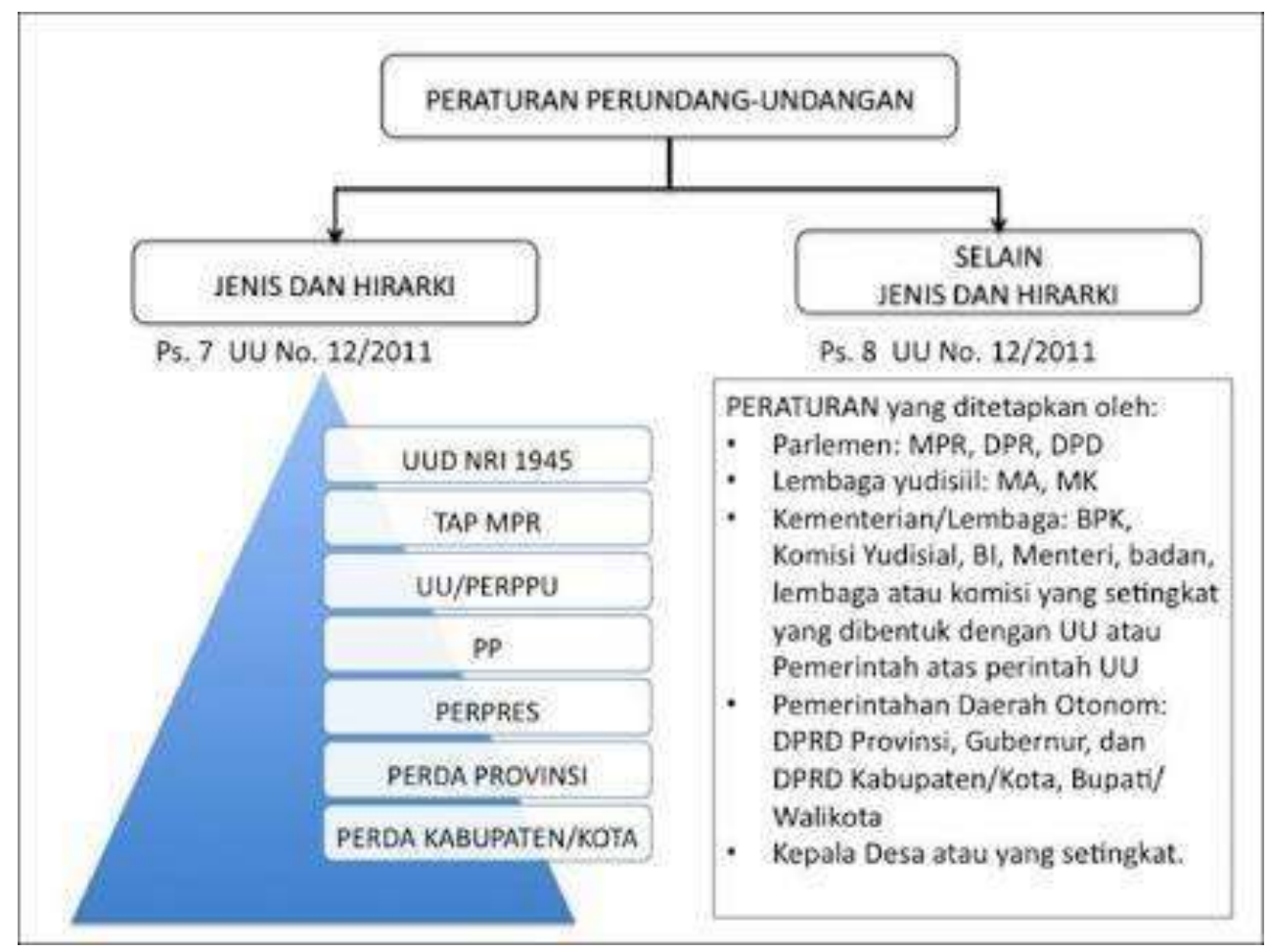

Gambar 4.1 Hierarki Peraturan Perundang-Undangan Negara Republik Indonesia

Tujuan hukum itu sendiri ialah sesuatu yang dikehendaki oleh hukum yakni tercapainya keadilan dan kepastian hukum (perlindungan hukum). Tujuan untuk tetap memjaga ketertiban masyarakat dapat dicapai dengan cara melindungi kepentingankepentingan yang ada dalam masyarakat secara seimbang. Implementasi tujuan hukum tersebut dapat dilaksanakan dalam suatu negara berdasarkan atas hukum sehingga untuk mencapai tujuannya, hukum haruslah ditegakkan. Berhasil tidaknya penegakan hukum itu bergantung pada isi/substansi hukum (Substance of Law), struktur hukum (Structure of Law), dan budaya hukum (Legal Culture). 
Menurut teori Lawrence Meir Friedman, ahli sosiologi hukum menjelaskan bahwa, Substansi hukum disebut sebagai sistem substansial yang menentukan bisa tidaknya hukum itu dilaksanakan. Substansi berarti produk yang dihasilkan oleh orang/lembaga yang berada dalam sistem hukum yang meliputi keputusan dan aturan baru yang mereka keluarkan. Substansi hukum juga mencakup hukum yang hidup (Living Law), bukan hanya aturan yang ada dalam kitab undang-undang (Law Books). Sebagai Negara yang menganut sistem civil law dikatakan hukum adalah peraturan-peraturan yang tertulis sedangkan peraturan-peraturan yang tidak tertulis bukan dinyatakan hukum. Sistem ini yang mempengaruhi hukum di Indonesia, salah satunya adalah adanya asas legalitas dalam KUHP, sebagaimana yang disebutkan dalam pasal 1 KUHP "tidak ada suatu perbuatan pidana yang dapat dihukum jika tidak ada aturan yang mengaturnya”. Terpenuhi atau tidaknya suatu perbuatan yang dapat dikenai sanksi hukum yakni apabila perbuatan tersebut sudah mendapatkan cara pengaturannya dalam peraturan perundangundangan.

Yang kedua, struktur hukum/pranata hukum, freidman menyebut bahwa sistem struktural yang menentukan bisa atau tidaknya hukum itu dilaksanakan dengan baik. Pranata hokum tersebut berdasarkan UU No. 8 Tahun 1981 mencakup; kepolisian, kejaksaan, pengadilan dan badan pelaksana pidana (lapas). Kewenangan lembaga penegak hukum dijamin oleh undang-undang. Sehingga dalam melaksanakan tugas dan tanggung jawabnya terlepas dari pengaruh kekuasaan pemerintah dan penagruh-pengaruh lain. Sebagaimana adagium yang menyatakan "fiat justitia et pereat mundus" meskipun dunia ini runtuh hukum harus ditegakkan. Hukum tidak akan dapat berjalan atau tegak bila tidak ada aparat penegak hukum yang kredibilitas, kompeten dan independen. Sebagus apapun suatu peraturan perundang-undangan bila tidak didukung dengan aparat penegak hukum yang baik maka keadilan hanya angan-angan. Lemahnya proses pengawasan (kontrol) dan integritas dari aparat penegak hukum mengakibatkan penegakkan hukum tidak berjalan sebagaimana mestinya.

Kemudian yang ketiga freidman menyebutkan budaya hukum/kultur hukum adalah sikap manusia terhadap hukum dan sistem hukum-kepercayaan, nilai pemikiran, serta harapannya. Budaya hukum adalah suasana, situasi ataupun kondisi pemikiran sosial dan kekuatan sosial yang menentukan bagaimana hokum tersebut digunakan, dihindari, atau 
disalahgunakan. Budaya hukum ini sangat berkaitan erat dengan kesadaran hukum masyarakat. Karna semakin tinggi kesadaran hukum masyarakat maka akan menjadikan budaya hukum yang baik dan dapat merubah pola pikir masyarakat mengenai hukum selama ini. Secara lugas, tingkat kepatuhan masyarakat terhadap hukum merupakan salah satu indikator berfungsinya hukum. Korelasi antara tiga unsur sistem hukum itu sendiri dapat dianalogikan seperti pekerjaan mekanik. Struktur dianalogikan laksana mesin, substansi merupakan apa yang dikerjakan atau dihasilkan oleh mesin, dan budaya hukum ialah apa saja atau siapa saja yang memutuskan untuk menghidupkan dan mematikan mesin itu, serta memutuskan bagaimana mesin itu digunakan.

Hukum sendiri sebenarnya dapat dikatakan sebagai obat, yakni obat untuk "menyembuhkan" ketidakadilan dan ketidaktertiban dalam masyarakat. Wacana tentang efikasi hukum akan membawa kita pada tahapan awal hukum diciptakan. Apakah hukum tersebut dapat bekerja dengan baik dalam situasi tertentu yang hendah "diobati" melalui keberadaannya. Dengan kata lain, efikasi hukum mengandaikan pertanyaan tentang manjur atau tidaknya hukum yang akan diberlakukan.

Lain halnya dengan efektifitas hukum. Efektifitas hukum bicara pada tataran riil saat hukum diterapkan. Efektifitas hukum menjadi pertanyaan saat hukum yang hendak diberlakukan, karena dianggap efikasi, menemui berbagai macam variabel di lapangan dan mempengaruhi hasil. Hukum yang dianggap efikasi belum tentu efektif. Hukum barulah memenuhi fungsinya jika masyarakat memberikan diri untuk patuh. Dengan demikian, maka efektifitas hukum dapat dinilai dengan penerimaan mereka dan penerimaan tersebut ditandai dengan kepatuhan terhadap hukum.

\section{Pembentukan Budaya Hukum}

Perkembangan hukum di Indonesia ternyata tidak disertai dengan perkembangan masyarakatnya. Hal tersebut dikarenakan terjadinya ketidakcocokan antara nilai-nilai yang dipilih oleh pemerintah yang sengaja disiapkan untuk sistem hukum modern dengan nilai-nilai yang telah dihayati oleh masyarakat yang masih bersifat tradisional. Sehingga mengakibatkan masyarakat kita belum siap menerima sistem hukum modern tersebut dan berakibat pula hukum yang dibuat oleh pemerintah menjadi tidak bermakna bagi masyarakat. 
Persoalan yang kedua adalah persoalan tentang fungsi hukum kaitannya dengan pengaruh budaya hukum. Hukum dewasa ini tidak cukup hanya berfungsi sebagai control sosial saja, melainkan hukum diharapkan mampu untuk menggerakkan masyarakat agar bertingkah laku sesuai dengan cara/pola baru demi tercapaunya tujuan yang dicita-citakan. Berkaitan dengan tersebut, diperlukan adanya kesadaran hukum dari masyarakat sebagai jembatan yang menghubungkan antara peraturan hukum dengan tingkah laku anggota masyarakat. Kondisi yang demikian mengakibatkan apa yang telah diputuskan melalui hukum tidak dapat dilaksanakan dengan baik dalam masyarakat karena dianggap tidak sejalan dengan nilai, pandangan, dan sikap yang telah dihayati oleh masyarakat.

Perkembangan yang terjadi di Indonesia dapat dilihat bahwa struktur sosial bangsa ternyata tidak sesuai dengan hukum modern yang dipilih oleh penguasa sehingga berakibat banyak terjadi kepincangan pelaksanaan hukum modern itu sendiri. Menurut Lon Fuller, ada delapan (8) prinsip legalitas yang harus diikuti dalam membuat hukum, meliputi; (a) harus ada peraturannya terlebih dahulu; (b) peraturan itu harus diumu mkan; (c) peraturan itu tidak boleh berlaku surut; (d) perumusan peraturan harus dapat dimengerti oleh rakyat; (e) hukum tidak boleh meminta dijalankannya hal-hal yang tidak mungkin; (f) diantara sesama peraturan tidak boleh terdapat pertentangan satu sama lain; (g) peraturan harus tetap dan tidak boleh sering diubah-ubah; (h) harus terdapat keseuaian antara tindakan para pejabat hukum dengan peraturan yang telah dibuat.

Pedoman yang harus kita pegang dalam hal ini, sebaik apapun hukum yang dinuat pada akhirnya sangat ditentukan oleh budaya hukum yang berupa nilai, pandangan serta sikap dari masyarakat yang bersangkutan. Jika budaya hukum diabaikan, maka dapat dipastikan akan terjadi kegagalan dari sistem hukum modern yang ditandai dengan gejala munculnya berbagai gejala, misalnya seperti kekeliruan informasi mengenai isi peraturan hukum yang ingin disampaikan kepada masyarakat, muncul perbedaan antara apa yang dikehendaki oleh undang-undang dengan praktik yang dijalankan oleh masyarakat. Masyarakat lebih memilih untuk tetap bertingkah laku sesuai dengan apa yang sudah menjadi nilai-nilai dan pandangan dalam kehidupan mereka.

Hukum Negara alias hukum nasional yang tak bersesuai dengan hukum rakyat, tentu saja acapkali condong untuk tak akan dipilih rakyat, ata u kasarnya terkadang malah 
akan memperoleh perlawanan dari bawah. Sekalipun hukum Negara itu ditopang oleh sanksi yang dilaksanakan secara terorganisasi oleh organisasi eksekutif, namun karena pada umumnya hukum Negara ini kurang dikenal atau dipandang kurang menguntungkan masyarakat luas, maka hukum Negara ini cenderung untuk terabaikan begitu saja. Menghadapi kenyataan seperti ini, sanksi hukum Negara seakan-akan kehilangan legitimasinya dan kehilangan pula daya keefektifannya. persoalannya memang bukan lagi berupa pelanggaran hukum oleh seorang atau dua orang yang berkesadaran hukum,-yang kalau saja demikian-tentunya akan dikoreksi dengan penjatuhan sanksi terhadapnya. Persoalannya yang paling mendasar adalah persoalan keyakinan dan kesadaran hukum rakyat yang merujuk ke perangkat budaya yang berbeda dari postulat yang diambil sebagai premis kebijakan Negara. Maka, pada hakikatnya yang tengah dihadapi ini adalah persoalan konflik budaya dalam suatu masyarakat nasional yang berkeadaan plural dalam soal budaya masyarakatnya, sekalipun satu dalam makna politik dan pemerintahannya. Membaca hukum dan konstitusi jangan hanya melihat bentuk formal dan formulasi tekstualnya saja. Tetapi juga kontekstual eksternal (budaya) yang mempengaruhi perumusannya. Merujuk kepada skema pemikiran Gert $\mathrm{H}$ Muller yang diinterpretasikan oleh Shidarta, mengenai pembentukan budaya hukum. 


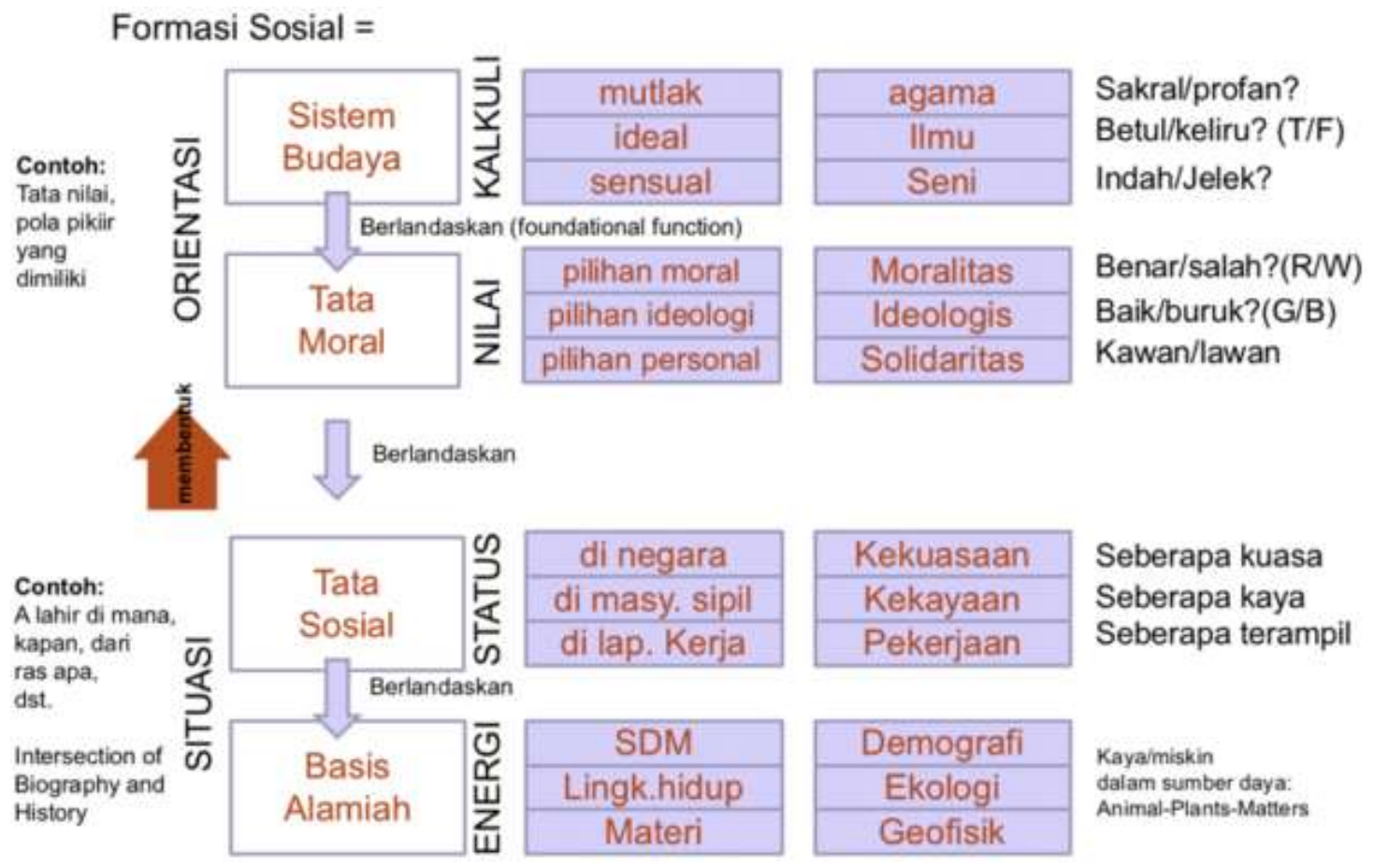

\section{Gambar 4.2 Pembentukan Budaya Hukum}

Semua hal diatas merupakan orientasi kesadaran sosial. Orientasi ini dibentuk dari situasi sosial. Dengan kata lain tidak aka nada orientasi sosial tanpa basis sosial yang mengacu pada ruang dan waktu tertentu. Situasi sosial tersebut, dibagi menjadi basis alamiah dan tata sosial. Pada basis alamiah terdapat tiga subdomain yaitu demografi, ekologi dan geofisika. Sementara itu, ada tiga subdomain dari tata sosial, yang masingmasing terjadi distruktur kekuasaan Negara, struktur permodalan/kelas sosial, dan struktur pekerjaan. Barulah kemudian ada basis sosial berupa sumber daya manusia (demografi), lingkungan hidup (ekologi) dan materi (geofisik).

Dengan menggunakan landasan berpikir ini, maka budaya hukum pun pada level paling dasar berangkat dari situasi basis alamiah. Basis ini sangat berenergi, disitu ada sumber daya manusia (demografi), lingkungan hidup (ekologi), dan materi (geofisik). Situasi berikutnya adalah tata sosial, yang meliputi struktur kekuasaan Negara, struktur permodalan/kelas sosial, dan struktur pekerjaan. Situasi pada tata sosial ini membentuk status sosial karena didalamnya akan tercermin siapa-siapa saja yang menduduki kekuasaan pada semua struktur itu. Kemudian tata moral dan sistem budaya, oleh karena 
hukum positif adalah juga tawaran nilai-nilai yang datang dari pemegang kekuasaan public, maka dapat diduga bahwa pembentukan budaya hukum yang sehat akan menghadapi masalah serius pada level ini apabila tawaran-tawaran itu terus menerus diingkari dengan alasan ketidakpercayaan pada pesan-pesan kebaikan dari sistem hukum positif.

\section{Upaya Perbaikan Hukum Dagang, Investasi dan Penanaman Modal}

Semakin berkembangnya zaman semakin berkembang pula metode dan teknik perniagaan, karna itu kebutuhan hukum perniagaan atau hukum dagang akan semakin bertambah. Lambat-laun hukum dagang yang pada waktu itu masih merupakan hukum kebiasaan dipandang perlu diadakan kodifikasi. Kodifikasi hukum dagang yang pertama dilakukan di Perancis atas perintah Raja Lodewijk XIV, yaitu Ordonance du Commerce 1673 dan Ordonance de la Marine 1681. Sedangkan di Indonesia sendiri, berdasarkan Pasal II aturan peralihan UUD 1945, maka Kitab Undang-Undang Hukum Dagang (KUHD) masih berlaku sebagaimana yang diumumkan melalui publikasi pada tanggal 30 April 1847 (S.1847 - 23) yang berlaku pada tanggal 1 Januari 1848. KUHD Indonesia tersebut merupakan turunan dari "Wetboek van Koophandel" (W.v.K) yang dibuat atas dasar azaz konkordansi (Pasal 131 I.S.). W.v.K tersebut berlaku mulai tanggal 1 Oktober 1838 dan 1 Januari 1842 di Limburg. W.v.K tersebut diadopsi dari "Code du Commerce" yang berasal dari Perancis tahun 1808. Tetapi tidak semua lembaga hukum yang diatur dalam "Code du Commerce" milik Perancis tersebut diambil alih oleh Wetboek van Koophandel (W.v.K) milik belanda. Ada beberapa hal yang tidak diambil, misalnya mengenai peradilan khusus tentang perselisihan-perselisihan dalam lapangan perniagaan (Speciale handelsrechtbanken).

Hukum dagang adalah hukum perdata khusus bagi kaum pedagang. Pada Pasal 2 (lama) KHUD yang berbunyi "Pedagang adalah mereka yang melakukan perbuatan perniagaan (daden van koophandel) sebagai pekerjaannya sehari-hari. Perbuatan perniagaan menurut pasal 3 (lama) KHUD menjelaskan bahwa Perbuatan perniagaan pada umumnya adalah perbuatan pembelian barang-barang untuk dijual lagi. Dalam pasal tersebut maksud "perbuatan perniagaan" hanya perbuatan pembelian saja, sedangkan perbuatan penjualan tidak masuk didalamnya, karena penjualan merupakan tujuan dari perbuatan pembelian itu (membeli barang untuk dijual lagi). 
Pengertian "barang" dalam pasal tersebut berarti "barang bergerak" tidak termasuk barang tetap. Selain dalam pasal 3 (lama), perbuatan perniagaan juga diatur dalam pasal 4 (lama), yang memasukkan beberapa macam perbuatan lain dalam pengertian perbuatan perniagaan, yaitu perbuatan-perbuatan yang mengenai; (1) Perusahaan kommis; (2) Perniagaan wesel dan surat-surat berharga dan lainnya; (3) Pedagang, banker, kasir, makelar dan sejenisnya; (4) Pembangunan. Perbaikan dan perlengkapan kapal untuk pelayaran dilaut; (5) Ekspedisi dan pengangkutan barang-barang; (6) Rederij, carter mencarter kapal, bodemerij dan perjanjian lain-lain tentang perniagaan laut; (8) Memperkerjakan nakhoda dan anak kapal untuk kepentingan kapal niaga; (9) Perantara/ makelar laut, cargdoor, convooilopers, pembantu-pembantu pengusaha perniagaan dan lain-lain; (10) Perusahaan asuransi.

Selain itu pasal 5 (lama) KHUD juga mengatur tentang perbuatan perniagaan yang bunyi singkatnya yaitu Perbuatan-perbuatan yang timbul dari kewajiban-kewajiban menjalankan kapal untuk melayari laut, kewajiban-kewajiban yang mengenai tubrukan kapal, menolong dan menyimpan barang-barang dilaut yang berasal dari kapal karam atau kapal terdampar, begitu pula penemuan barang-barang di laut, pembuangan barangbarang dilaut pada waktu ada averij, itu semua termasuk dalam golongan perbuatan perniagaan. Pasal 2-5 (lama) KHUD tersebut termasuk dalam Bab I KHUD yang berjudul "Tentang Pedagang dan Perbuatan Perniagaan". Pasal-pasal tersebut telah dicabut dengan S.1938-276, yang mulai berlaku pada tanggal 17 Juli 1938.

Namun pasal-pasal tersebut (Pasal 2, Pasal 3, Pasal 4 dan pasal 5) telah dihapus dalam KHUD Indonesia Bab I pada Buku Kesatu yang menjelaskan perniagaan atau dagang secara filosofi hingga sekarang belum ada upaya untuk pembaharuan. Padahal semakin berkembangnya jaman makna dan metode perniagaan atau dagang juga semakin berkembang ditambah lagi dengan kemajuan teknologi yang semakin memudahkan akses atau hubungan dagang tersebut. Langsung kepada Bab II KHUD Indonesia mengatur tentang pembukuan, berkaitan dengan perdagangan, guna untuk memberikan informasi mengenai setiap transaksi. Pada dasarnya ketika hukum dagang ini diatur secara jelas maka akan lebih mumudahkan langkah pemerintah untuk menentukan kebijakan selanjutnya guna meningkat investasi, dan juga dengan mudah dapat memperbaiki dan menentukan sistem perpajakan. 
Hukum dagang Indonesia terutama bersumber pada; yang pertama, Hukum tertulis yang dikodifikasikan yakni Kitab Undang-Undang Hukum Dagang (KHUD) atau Wetboek van Koophandel (WVK) dan Kitab Undang-Undang hukum Perdata (KUHPerdata) atau Burgerlijk Wetboek (BW), Buku III tentang Perikatan. Yang kedua Hukum tertulis yag belum dikodifikasikan yakni peraturan perundangan khusus yang mengatur tentang hal-hal yang berhubungan dengan perdagangan diantaranya (1) UU No. 40 Tahun 2007 tentang Perseroan Terbatas; (2) UU No. 8 Tahun 1995 tentang Pasal Modal; (3) UU No. 32 Tahun 1997 tentang Perdagangan Berjangka Komoditi; (4) UU No. 8 Tahun 1997 tentang Dokumen Perusahaan. Dan yang ketiga, Hukum kebiasaan yakni (i) Pasal 1339 KUHPerd ; Suatu perjanjian tidak saja mengikat untuk apa yang semata-mata telah diperjanjikan tetapi untuk apa yang sudah menjadi kebiasaan; (ii) Pasal 1347 KUH Perd : hal-hal yang sudah lazim diperjanjikan dalam suatu perjanjian, meskipun tidak secara tegas diperjanjikan harus dianggap juga tercantum dalam setiap perjanjian semacam itu.

Terkait dengan sumber hukum dagang tersebut diatas, kenapa tidak dilakukan upaya pembaharuan hukum dagang sebagai upaya kodifikasi agar menghasilkan sebuah menghasilkan sebuah kitab undang-undang, yang mungkin didalam nya termasuk, hukum dagang, hukum investasi, hukum ketenagakerjaan, hukum perdata. Mengingat kodifikasi merupakan cirri khas Negara-negara dengan sistem hukum sipil (civil law).

Jika omnibus law diciptakan dengan tujuan untuk meng-unifikasi berbagai peraturan perundang-undangan yang secara fundamental saling terkait agar tidak terjadi benturan (tumpang tindih) antar undang-undang lain, kenapa tidak dilakukan hal yang sama untuk tujuan yang paling mendasar yaitu melakukan pembaharuan hukum dagang dalam upaya meningkatkan investasi. Sejatinya investasi paling dekat kaitannya dengan hukum dagang, kejelasan hukum dagang akan memperjelas ruang dan arah investasi serta mempermudah menentukan kebijakan perpajakan dan lapangan pekerjaan. Misalkan saja "Perusahaan Google" atau yang berbasis e-commerce agak sulit untuk menetapkan atau memungut pajak nya dikarenakan kurang jelasnya aturan hukum dagang yang mengaturnya. Adapun yang diatur hanya terkait asas territorial dan asas domisili dalam sistem perpajakan. Namun ketika pembaharuan hukum dagang itu dilakukan, terkait dengan asas territorial atau domisili ini pun lebih dipertegas mungkin 
menemukan titik terang untuk memungut pajak dari usaha yang berbasis e-commerce tersebut. Karna di turki pun telah mencoba membuat kebijakan pajak pada perusahaan over the top kurang lebih sebesar 7,5\% pada perusahaan sekaliber Google dan Facebook, serta pasar elektronik seperti eBay, dan platform e-commerce seperti Spotify dan Netflix.

Hukum ekonomi internasional lebih banyak mengatur subjek hukum yang bersifat publik (policy), misalnya seperti hubungan-hubungan dibidang ekonomi yang dilakukan oleh negara atau organisasi internasional. Sementara itu, hokum perdagangan internasional lebih menekankan kepada hubungan-hubungan hukum yang dilakukan oleh badan-badan hokum privat. Kenyataannya pendirian tersebut tidak begitu valid, karna hokum ekonomi internasional juga mengatur kegiatan-kegiatan atau transaksi badan hokum privat atau yang terkait dengan kepentingan privat, misalnya saja mengenai perlindungan dan nasionalisasi atau eksploitasi perusahaan asing. Prinsip Hukum perdagangan Internasional pun dibagi menjadi empat substansi:

1. Prinsip Dasar Kebebasan Berkontrak, prinsip ini sering disebut dengan Partij Autonomie. Prinsip ini berlaku disemua Negara, inti dari prinsip ini adalah jika ingin terikat dalam perdagangan, harus diberikan kebebasan untuk berkehendak atau Meeting of Minds. Di Indonesia suatu perjanjian dinyatakan sah apabila (Pasal 1320 KUH Perdata); (a) adanya kata sepakat dari kedua belah pihak; (b) kecakapan untuk melakukan perbuatan hukum; (c) adanya sebab (kausa) yang hala1/legal. Kata sepakat dan kecakapan bersifat subjektif dan jika dilanggar maka perjanjian tersebut menjadi "Voidable" (dapat dibatalkan). Sedangkan objek/ hal tertentu dan sebab (kausa) bersifat objektif dan jika dilanggar maka perjanjian tersebut menjadi "Null \& Void" (batal demi hukum).

2. Prinsip Dasar Pacta Sunt Servanda, yaitu mensyaratkan bahwa kesepakatan atas kontrak yang telah ditandatangani harus dilaksanakan dengan sebaikbaiknya (dengan itikad baik). Prinsip ini pun bersifat universal dan setiap sistem hukum didunia menghormati prinsip ini.

3. Prinsip Dasar Penyelesaian Sengketa melalui Arbitrase, penyelesaian sengketa dapat ditempuh dengan dua jalur, yakni melalui pengadilan dan diluar pengadilan. Penyelesaian sengketa dengan menggunakan arbitrase merupakan penyelesaian sengketa diluar pengadilan. Di Indonesia terdapat suatu lembaga arbitrase yang terkenal yakni BANI (Badan Arbitrase Nasional Indonesia). 
4. Arbitrasi sendiri dalam perdagangan internasional adalah forum penyelesaian sengketa yang semaiin umum digunakan. Klausul arbitrase sudah semakin banyak dicantumkan dalam kontrak-kontrak dagang. Oleh karena itulah, prinsip ketiga ini memang relevan.

Luasnya cakupan hukum perdagangan internasional ini membuat cakupan yang dikaji sulit untuk tidak tumpang tindih dengan bidang-bidang lainnya, misalnya seperti hukum ekonomi internasional, hukum transaksi bisnis internasional dan lain-lainnya. Selain melibatkan Negara-negara dan lembaga-lembaga internasional berdasarkan ketentuan GATT-WTO, juga melibatkan para pihak Negara yang berbeda yang melakukan transaksi dagang internasional. Dalam perdagangan internasional tentu saja terdapat konflik-konflik yang terjadi. Adapun konflik tersebut dapat terjadi antara Negara yang menganut keluarga civil law dengan Negara yang menganut common law. Lalu bagaimana penyelesaiannya, dapat digambarkan sebagai berikut:

Siapa Pihak (subjek) yang dimaksud?

- Negara

- Organisasi Perdagangan Internasional

- Individu

- Perusahaan Internasional

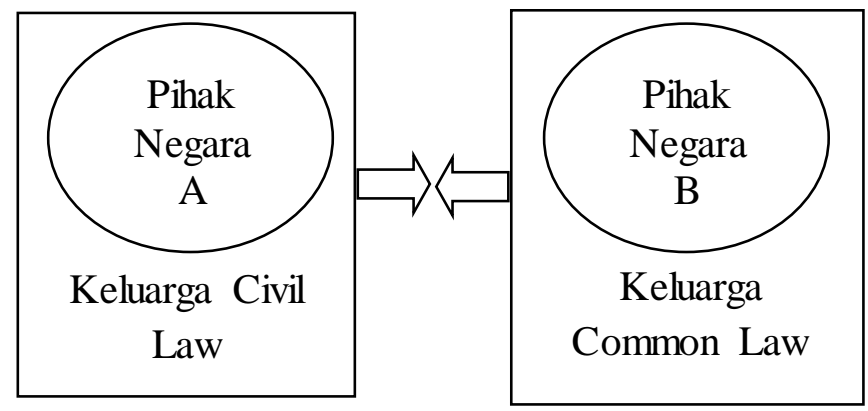

- Bank

\section{Gambar 4.3 Pihak Menurut GATT-WTO}

Jika kedua pihak Negara tersebut mengalami konflik dibidang hukum maka ada tiga kemungkinan yang akan diambil untuk menyelesaikan konflik tersebut; (1) tiap pihak tidak memakai hukum nasionalnya, tetapi memakai hukum perdagangan internasional; (2) membuat klausul pilihan hukum (choice of law) pada atas salah satu hukum nasional tersebut; (3) menggunakan aturan yang telah diunifikasi atau diharmonisasi.

Unifikasi ialah penyeragaman yang mencakup penghapusan dan penggantian suatu

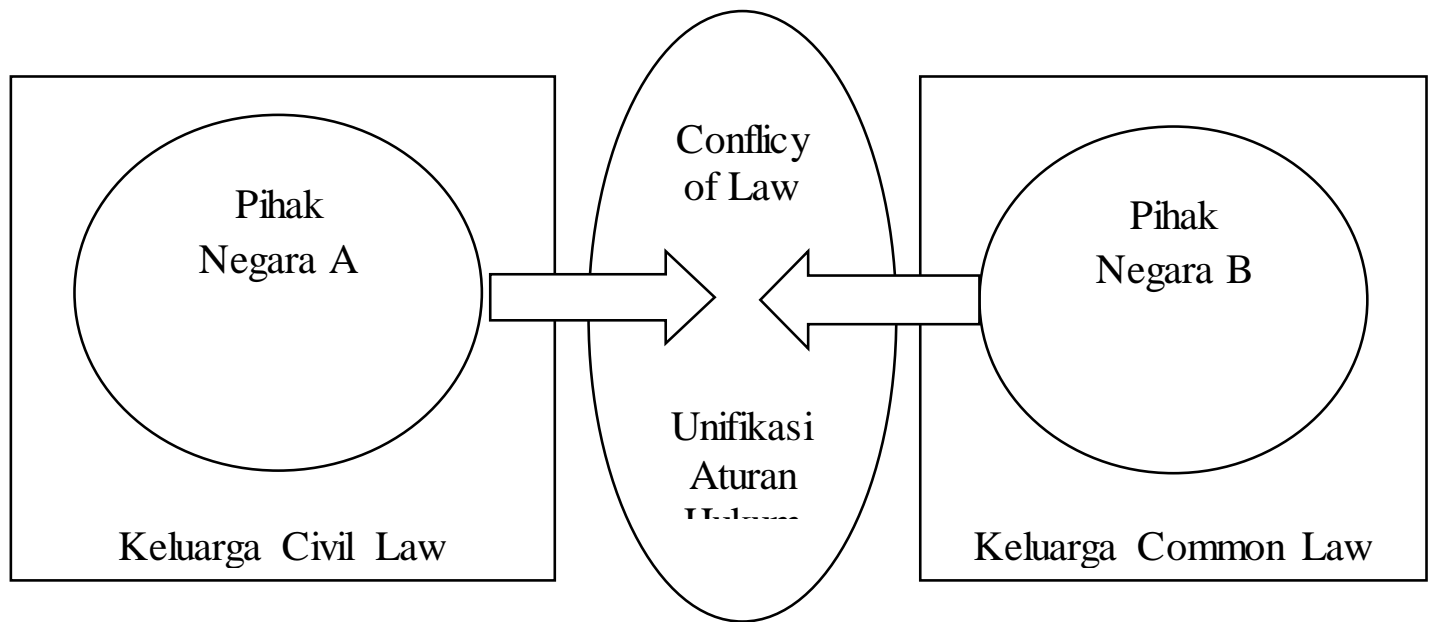


sistem dengan sistem hukum baru.

\section{Gambar 4.4 Sistem Hukum}

Aturan sama sekali tidak mengacu pada kehendak salah satu pihak, tetapi berdasarkan pada perjanjian internasional. Tiap Negara wajib menyesuaikan aturan hukum nasionalnya dengan isi perjanjian internasional itu. Contoh Unifikasi : Hak Kekayaan Intelektual (Intellectual Property Rights). Ada suatu orgnisasi dunia yang tugasnya melindungi Patents (Hak Paten), Copyrights (Hak Cipta), dan Trade Secret, Organisasi tersebut ialah TRIPS/ WTO (Trade Related aspects of Intellectual Propertie Rights/ World Trade Organization). TRIPS mewajibkan Negara-negara anggota WTO untuk memenuhi (i) Article I s.d XXI dan Appendix Berne Convention; (ii) Article I s.d XII, dan XIX Paris Convention.

Kemudian upaya harmonisasi yakni upaya mencari keseragaman atau titik temu dari prinsip-prinsip yang bersifat fundamental dari berbagai sistem hukum yang ada dan akan diharmonisasikan. Mencari prinsip-prinsip yang sama (titik temu) dari hukum tiap

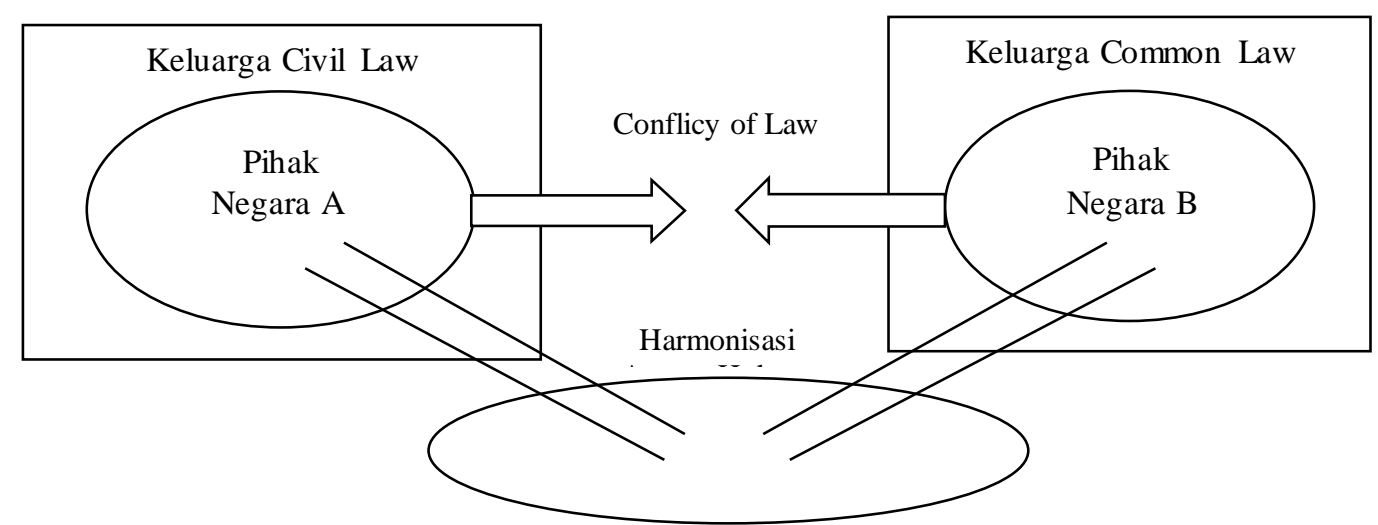

Negara lalu gunakan sebagai aturan bersama. Contohnya asas "pacta sun servanda".

\section{Gambar 4.5 Metode Komparatif Schimtthoff}

Metode Komparatif Schimtthoff untuk melakukan unifikasi/harmonisasi:

1. Perjanjian atau Konvensi Internasional (International Convention); paling banyak digunakan dengan jalan memperkenalkan hukum perdagangan internasional ke hukum nasional. Misalnya perjanjian TRIPS/WTO.

2. Hukum Seragam (Uniform Laws); Misalnya, UNCITRAL 1985 (Model Law on International Commerdial Arbitration) dengan keleluasaan Negara 
menerapkannya.

3. Aturan Seragam (Uniform Rules); Misalnya, The Uniform Customs and Practice for Documentary Credits (1974) yang dikeluarkan oleh para subjek hukum perdagangan internasional.

The World Trade Oragnization (WTO) merupakan paying yang menangungi 28 jenis persetujuan yang mengatur tentang perdagangan barang, perdagangan jasa dan perlindungan hak kepemilikan intelektual serta investasi yang berhubungan dengan perdagangan. Mekanisme penyelesaian sengketa dalam perjanjian WTO sekarang ini pada intinya mengacu pada ketentuan Pasal 22-23 GATT 1947, dengan berd irinya WTO, ketentuan GATT 1947 kemudian melebur ke dalam aturan WTO.

Untuk mengantisipasi kemajuan dalam bidang ekonomi, dan semakin majunya lalu lintas perdagangan baik ditingkat nasional maupun internasional (global dan regional), Indonesia memerlukan instrumen hukum baru yang dapat menyelesaikan permasalahanpermasalahan hokum dalam bidang ekonomi dan perdagangan yang semakin berkembang dewasa ini. Hal ini diperlukan karena banyaknya persoalan hhukum yang menyangkut masalah-masalah ekonomi atau bisnis yang belum diatur dalam KUH Perdata maupun KUHD yang berlaku di Indonesia.

Dengan ditandatannganinya hasil perundingan Uruguay Round telah membawa konsekuensi yuridis bagi Indonesia, yang artinya Indonesia harus melakukan harmonisasi peraturan perundang-undangan nasional sesuai hasil kesepakatan WHO, misalnya saja dengan diundangkannya UU No. 7 Tahun 1994 tentang Persetujuan Berdirinya WTO, UU No. 19 Tahun 1995 tentang Kepabeanan yang kemudian dirubah lagi dengan UU No. 17 Tahun 2006 yang antara lain mengatur tentang ketentuan antidumping, pelarangan subsidi dan tindakan pengamanan (Safeguard). Sebagai tindak lanjutnya dari dukungan tersebut, pemerintah Indonesia telah menentukan arak kebijaksanaan di bidang hokum yang mendukung kegiatan ekonomi sebagaimana dituangkan dalan Garis-Garis Besar Haluan Negara (GBHN) 1999-2004, Tap MPR No.IV/MPR/1999. Hal ini telah dinyatakan dalam butir 7, bahwa Indonesia harus mengembangkan peraturan perundang-undangan yang mendukung kegiatan perekonomian dalam menghadapi era perdagangan bebas tanpa merugikan kepentingan nasional. 
Selanjutnya, di Indonesia sendiri hukum dagang dan investasi termasuk dalam bidang hukum perdata yang artinya bersifat khusus (privat), yang terkait dengan perjanjian-perjanjian. Sebagian lagi masuk dalam hukum perijinan yang dapat dikelompokkan dalam hukum administrasi negara atau bagian hukum publik. Sementara Omnibus Law adalah produk undang-undang yang diciptakan untuk menghilangkan tumpah tindah antar peraturan perundang-undangan yang bersifat fundamental. Mungkin langkah ini agak keliru, karna sebelum menyatukan yang bersifat fundamental seharusnya dilakukan upaya perbaikan dan pembaharuan secara fundamental terlebih dahulu, untuk memperjelas ruang dan arah kebijakan yang dibuat. Berikut ini beberapa peraturan perundang-undangan yang pernah dikeluarkan pemerintah Indonesia dalam rangka menjadi dasar atau acuan pengaturan perdagangan internasional antara lain; (1) UU No. 10 Tahun 1995 tentang Kepabeanan; (2) UU No. 17 Tahun 2006 tentang Perubahan UU No. 10 Tahun 1995 tentang Kepabeanan; (3) PP No. 34 Tahun 1996 tentang Bea Masuk Antidumping dan Bea Masuk Imbalan; (4) Keputusan Menteri Perindustrian dan Perdagangan No. 136/MPP/Kep/6/1996 tentang Pembentukan Komite Antidumping Indonesia; (5) Keputusan Menteri Perindustrian dan Perdagangan No. 172/MPP/Kep/6/1996 tentang Organisasi dan Cara Kerja Tim Organisasi Antidumping; (6) Keputusan Menteri Perindustrian dan Perdagangan No. 427/MPP/Kep/10/2000 tentang Komite Antidumping Indonesia; (7) Keputusan Menteri perindustrian dan Perdagangan No. 428/MPP/Kep/10/2000 tentang Pengangkatan Anggota Komite Antidumping Indonesia; (8) Keputusan Menteri Perindustrian dan Perdagangan N. 216/MPP/Kep/7/2001 tentang Perubahan Keputusan Menteri Perindustrian dan Perdagangan No. 261/MPP/Kep/9/1996 tentang Tata Cara Persyaratan Pengajuan Penyelidikan Atas Barang Dumping dan Barang Mengandung Subsidi; (9) Peraturan Menteri Perdagangan Republik Indonesia No. 37/M-Dag/Per/9/2008 tentang Surat Keterangan Asal (Certificate of Origin) Terhadap Barang Impor yang dikenakan Tindakan Pengamanan (Safeguard).

Tujuan dari penerapan peraturan-peraturan tersebut untuk meningkatkan pertumbuhan ekonomi terutama sektor usaha mikro, kecil dan menengah yang merupakan salah satu faktor penting dalam perekonomian nasional. Karna sektor usaha tersebutlah yang akan berdampak positif ataupun negatif dari pemberlakuan GATT- 
WTO terlebih menghadapi pasar bebas ASEAN pasca AFTA tahun 2003, diikuti oleh pasar bebas CAFTA 2010 dan kini APEC yang mulai berlaku pada 2020 untuk Negara berkembang.

Selain itu, di sisi lain juga perlu lebih memahami hukum investasi, maka perlu dipahami konsideran atau bagian menimbang dan UU No. 1 Tahun 1976 tentang PMA dan UU No. 6 Tahun 1968 PMDN serta UU No. 25 Tahun 2007 tentang Penanaman Modal dan sektor-sektor mana yang tertutup dan terbuka dan syarat Indonesianisasi pemegang saham tidak sekaligus menjelang tahun ke-10 akan tetapi bertahap setelah 5 Tahun produksi komesial dan menjelang tahun ke-10.

Mengenai personalitas usaha terdapat beberapa istilah-istilah, yang dikenal dalam KHUD terdiri dari Pedagang dengan usaha sendiri, yang wajib pembukuan dan tidak wajib memelihara pembukuan telah dihapus, dan kategorinya lebih ditentukan bukan penamaan profesi pedagang, akan tetapi penekanan wajib pembukuan lebih kepada jumlah omset. Maka tinggal bentuk personalitas usaha yang tersedia oleh hukum dagang atau hukum bisnis adalah Firma $(\mathrm{Fa})$ atau $\mathrm{CV}$, yang akte pendiriannya harus dalam bentukk formal berupa akte notaris, dan menurut ketentuan perpajakan telah wajib pembukuan bila omsetnya melebihi 4,8M pertahun/jumlah peredaran bruto, atau dapat dipersamakan dengan pedagang yang melakukan kegiatan usaha atau pekerjaan bebas (omsetnya dibawah 4,8M pertahun) cukup melakukan pencatatan saja (pajaknya atas dasar norma - pasal 14 (2) UU PPh) atau seharusnya masuk kategori pedagang.

Disamping itu ada istilah bukan pedagang (untuk kepentingan umum, sosial, keagamaan atau ideal tertentu). Terhadap yang bukan pedagang berlaku ketentuan umum dalam BW (burgerlijk Wetboek). Terhadap yang setengah/separo pedagang, maka hanya tunduk pada sebagian ketentuan KUHD atau dengan penundukan diri secara sukarela bila dalam kegiatan usahanya memakai warkat-warkat surat-surat berharga. Sedangkan pedagang atau pedagang penuh, maka seluruh ketentuan KUHD berlaku baginya. Dari segi aspek hukum pembuktian terlihat sekali perbedaan konsekuensi berlaku KUHD atau BW. Perbedaan perlakuan antara pedagang dan bukan pedagang (diluar KUHD) akan lebih dapat dirasakan dalam hal hukum pembuktian dan pilihan peradilan yang tersedia. Jika ketentuan dalam hukum dagang (KUHD), cukup sudah terbukti bila ia mengaku tanda tangannya diatas warkat atau surat berharga adalah tanda tangannya. Sedangkan 
kepada bukan pedagang, ia dianggap sudah mengerti hukum perdata (BW), untuk warkat dibawah tanga seperti pengakuan hutang perlu ada dua saksi untuk lebih memperkuat dan mengukuhkan kesaksiannya. Juga bila pedagang atau pengusaha tidak berhasil usahanya, sehingga modalnya menurun drastis hingga 1/4 nya maka bila diproses pailit maka sudah ada peradilan khusus untuknya yaitu Peradilan Niaga.

Kategori pengertian ini hampir sama dengan pengertiannya atau kategori personalitas dalam hukum pajak yaitu orang pribadi usahawan (pedagang) atau badan. Badan usaha ini terdiri dari BUMN, BUMD, PT Penanaman Modal (fasilitas) dan PT Non Fasilitas (PT Biasa), BUT atau Korporasi Asing tertentu, PT Tertutup/PT Biasa dan PT Terbuka (masuk bursa). Selain itu dikenal pula agen, distributor, representative office melalui Dirjendaglu atau melalui BKPM.

Semua ini masuk kategori Pengusaha (UU UKM) atau Pedagang (istilah KUHD) atau pengusaha/peniaga. Sedangkan kewajiban pembukuan bagi pedagang/pengusaha baru bila setelah omsetnya mencapai diatas 4,8M keatas. Kewajiban pembukuan ini terkait dengan cara perhitungan pajak. Bila ada pembukuan yang rapid an bukti-buktinya maka pembayaran yang dipilih berdasarkan pembukuan (berdasarkan pasal 6 KUHD, tidak tergantung jumlah omset) dan tidak dikenakan lagi berdasarkan norma. Ini pilihan yang dibenarkan dalam menghndari tariff pajak yang lebih besar dan tidak termasuk dalam pengelakan pajak.

Secara umum dalam bahasa sehari-hari pengusaha disebut partikelir atau wiraswasta atau swasta yang menyelenggarakan perusahaan dan ketentuan umum KUHD ini juga memperlakukan BW, sepanjang tidak diatur secara khusus dalam KUHD tentang orang atau badan yang menjalankan perusahaan. Seperti yang telah diuraikan diatas di Bab II mengatur Tentang dagang dan perbuatan dagang dalam ketentuan pasal 2-5 KUHD telah dihapuskan pada tahun 1938, dalam S.1938 : 276, mulai berlaku pada tanggal 17 Juli 1938.

\section{Kondifikasi Hukum Ekonomi dan Pembaharuan Hukum Tenaga Kerja}

Tujuan investasi adalah mempercepat laju pembangunan. Negara berkembang seperti Indonesia sangat lah membutuhkan investasi guna mempercepat laju pembangunan. Pada umum nya yang memiliki modal atau investasi adalah Negaranegara maju kepada Negara berkembang. Dalam teori Raymond Vernon (1966) tentang 
teori siklus produk (The Product Cycle Theory) menganalis faktor penyebab Negara maju menanamkan investasinya ke Negara berkembang. Teori tersebut cocok diterapkan pada investasi asing secara langsung (foreign direct investment) dalam bidang manufacturing, yang merupakan usaha ekspansi awal perusahaan Negara-negara maju. Namun menurut teori Kindleberger aspek yang paling sensitif dalam perekonomian internasional adalah aspek investasi langsung atau direct investment. Amerika serikat dan Inggris berusaha membatasi investasi langsung oleh perusahaan-perusahaan langsung yang berdomisili didalam batas-batas kedua Negara ini untuk membatasi tekanan pada neraca pembayaran mereka. Teori investasi langsung atau direct investment mempunyai banyak implikasi, yaitu:

1. Investasi langsung tidak akan terjadi dalam industri dimana ada persaingan murni.

2. Perusahaan penanam modal tidak berkepentingan untuk mengadakan usaha bersama atau joint venture dengan pengusaha setempat karena akan berusaha memiliki sendiri seluruh keuntungan; dan pada saat bersamaan para penanam modal setempat tentu tidak mau membeli saham-saham dan perusahaan induk serta penghasilan keseluruhan penanam modal menjadi kabur atau samar-samar dibandingkan dengan keadaan setempat yang dapat membawa banyak keuntungan sebagaimana mereka lihat.

3. Investasi langsung terjadi menurut dua arah industri yang sama, hal ini tidak akan terjadi apabila kegiatan didasarkan atas tingkat-tingkat laba umum. Hal ini untuk sebagian merupaka kejadian yang khas dalam persaingan oligopoli yaitu setiap perusahaan harus bertindak seperti dilakukan perusahaan yang lain untuk menghindari agar perusahaan lain tidak mendapatkan laba secara tidak terduga.

Kepentingan Negara dalam bidang investasi juga harus melihat sudut pandang kepentingan pembangunan ekonomi sebagai dasar pijakan perumusan kebijakan hukum investasi. Karena secara tak langsung foreign direct investment dimungkinkan menjadi ancaman terhadap kedaulatan host country dan terhadap kebebasan pembangunan kehidupan sosial dan budaya karena investasi asing cenderung memperluas yuridiksi menggunakan pengaruh kekuatan pemerintah asing terhadap host country sehingga politik investasi asing terhadap host country cukup besar. 
Dengan demikian perlu melihat pentingnya Negara yang otonom (yang berdaulat) yang mengarahkan langkah kebijakan ekonomi termasuk investasi, peran Negara dipercaya akan bisa mengintervensi pasar untuk mengoreksi ketimpangan pasar dan memberikan perlindungan kepada invant industries, kepentingan masyarakat, pengusaha domestik dan perlindungan lingkungan. Peran Negara juga dapat memberikan perlindungan bagi kepentingan para investor termasuk investor asing.

Menurut Jeremy Bentham dalam "Economic Analysis of Law" menguji secara sistematik bagaimana orang bertindak berhadapan dengan insentif-insentif hukum dan mengevaluasi hasil-hasil menurut ukuran-ukuran kesejahteraan sosial (social welfare). Pembentuk undang-undang hendaknya dapat memberikan kebahagiaan yang besar bagi sebagian besar masyarakat (the greatest happiness for the greatest number).

Dilemanya, peranan pemerintah dalam menciptakan iklim investasi untuk mengatasi kegagalan pasar (market failure) atau kegagalan laissezfaire mencapai efesien, dalam hal mengatasi kegagalan tersebut pemerintah dapat melakukan intervensi melalui hukum dan peraturan. Pemerintah mengatur dunia usaha transaksi untuk meminimalkan information asymmetries dan mencegah monopoli. Dalam praktiknya, pemerintah acapkali gagal mengurangi kegagalan pasar, bahkan tidak jarang intervensi dan pemerintah malah memperburuk iklim investasi. Untuk mengatasi hal tersebut pemerintah perlu menyusun kerangka acuan yang jelas agara kompetisi dapat berjalan dengan baik. Pengaturan yang baik akan menciptakan persaingan antar dunia usaha sehingga hanya perusahaan efisien yang dapat bertahan hidup. Serta membangun keyakinan calon investor untuk menanamkan modal atau investasi di Indonesia, kepastian hukum, perlindungan hukum (legal protection) dan keadilan hukum harus diutamakan karena investor yang menanamkan modalnya selain mengharapkan hasil atau keuntungan dalam bisnisnya, modal yang ditanamkannya juga tetap dalam posisi aman.

Karna itu diperlukan kerangka acuan yang mendasar, misalnya saja pembaharuan KUHD pada pasal-pasal yang telah dihapuskan terkait ketentuan dagang dan perbuatan dagang, karna semakin berkembangnya teknologi, maka makna ketentuan dagang dan perbuatan dagang akan semakin kabur (bias) dengan maraknya transaksi elektronik. Pada dasarnya semakin canggih dan maju teknologi maka pasar tenaga kerja juga akan semakin berkurang, kecerdasaran buatan (artificial intelligence) telah menggeser 
manusia, banyak perusahaan yang melakukan perampingan tenaga kerja (PHK) dikarenakan telah digantikan dengan teknologi dengan alasan menekan cost/ upah. Karna itu diperlukan kodifikasi hukum ekonomi dan pembaharuan hukum tenaga kerja sebagai upaya mengantisipasi gelombang revolusi industri 4.0.

Misalkan saja salah satu tujuan dari UU No. 13 Tahun 2003 tentang Ketenagakerjaan, yaitu memberikan perlindungan kepada tenaga kerja dalam mewujudkan kesejahteraan dan meningkatkan kessejahteraan tenaga kerja dan keluarganya. Karna hal ini dianggap penting dan menyangkut kepentingan umum, maka pemerintah mengalihkannya dari hukum privat menjadi hukum publik. Alasan lain adalah banyaknya masalah ketenagakerjaan yang terjadi baik dalam maupun luar negeri. Salah satu contohnya adalah banyak nya kasus yang masuk ke pengadilan hubungan industrial (PHI) menyangkut penggunaan tenaga kerja asing. Setiap putusan badan peradilan PHI akan menjadi evaluasi untuk kepentingan dibidang ketenagakerjaan.

Ternyata upaya penyusunan naskah akademik RUU KUHD pun telah dilakukan dalam rangka melaksanakan Program Legislasi Nasional Jangka Menengah 2010-2014. Dengan tujuan ingin menyempurnakan substansi dari KUHD agar terjadi keharmonisan di antara peraturan perundang-undangan di bidang hukum dagang. Pada tahun 19851986 mulai dirintis oleh BPHN dalam rangka pembinaan Hukum Nasional, dengan melakukan kodifikasi Hukum Dagang, tetapi belum ditindaklanjuti sehingga RUU Hukum Dagang ini dimasukkan kedalam daftar Prolegnas 2010-2014. Berikut persandingan Kodifikasi KUHD.

Tabel 4.1 Persandingan KUHD dengan Perundang-undangan yang Mengatur Secara Khusus

\begin{tabular}{|c|l|l|l|l|}
\hline No & \multicolumn{1}{|c|}{ Bidang } & \multicolumn{1}{|c|}{ KUHD } & \multicolumn{1}{c|}{$\begin{array}{c}\text { Peraturan } \\
\text { Perundangan } \\
\text { Terkait }\end{array}$} & \multicolumn{1}{|c|}{ Analisis } \\
\hline 1 & Kegiatan Usaha & & & \\
\hline & $\begin{array}{l}\text { a. Bentuk Badan } \\
\text { Usaha }\end{array}$ & & & \\
\hline & $\begin{array}{l}\text { 1) Non Badan } \\
\text { Hukum }\end{array}$ & $\begin{array}{l}\text { Buku I Bab III } \\
\text { Bagian 1 (Firma } \\
\text { dan Persekutuan } \\
\text { Komanditer) }\end{array}$ & $\begin{array}{l}\text { RUU ttg Persekutuan } \\
\text { Perdata, Firma dan } \\
\text { CV }\end{array}$ & $\begin{array}{l}\text { Proses legislasi utk } \\
\text { diatur tersendiri }\end{array}$ \\
\hline & $\begin{array}{l}\text { 2) Perseroan } \\
\text { Terbatas }\end{array}$ & $\begin{array}{l}\text { Buku I Bab III } \\
\text { Bagian 2 }\end{array}$ & $\begin{array}{l}\text { UU No. 40/2007 ttg } \\
\text { Perseroan Terbatas }\end{array}$ & $\begin{array}{l}\text { Diatur tersendiri } \\
\text { dan dikeluarkan }\end{array}$ \\
\hline
\end{tabular}




\begin{tabular}{|c|c|c|c|c|}
\hline & & (Perseroan) & & dari KUHD \\
\hline & 3) Koperasi & Tidak diatur & $\begin{array}{l}\text { UU No. 25/1992 ttg } \\
\text { Koperasi }\end{array}$ & Diatur tersendiri \\
\hline & 4) Yayasan & Tidak diatur & & Diatur tersendiri \\
\hline & 5) BUMN & Tidak diatur & $\begin{array}{l}\text { UU No. 19/2003 ttg } \\
\text { BUMN }\end{array}$ & Diatur tersendiri \\
\hline & 6) BUMD & Tidak diatur & $\begin{array}{l}\text { UU No. 5/1962 ttg } \\
\text { Perusahaan Daerah }\end{array}$ & Diatur tersendiri \\
\hline & $\begin{array}{l}\text { 7) Usaha Mikro, } \\
\text { Kecil dan } \\
\text { Menengah }\end{array}$ & Tidak diatur & $\begin{array}{l}\text { UU No. 20/2008 ttg } \\
\text { Usaha Mikro, Kecil } \\
\text { dan Menengah }\end{array}$ & Melengkapi \\
\hline & $\begin{array}{l}\text { b. Urusan } \\
\text { Perusahaan }\end{array}$ & & & \\
\hline & 1) Wajib Daftar & $\begin{array}{l}\text { Ps. } 6-\text { Ps } 12 \\
\text { KUHD }\end{array}$ & $\begin{array}{l}\text { UU No. 3/1982 ttg } \\
\text { Wajib Daftar } \\
\text { Perusahaan }\end{array}$ & Melengkapi \\
\hline & 2) Pembukuan & $\begin{array}{l}\text { Ps. } 6-\text { Ps } 12 \\
\text { KUHD }\end{array}$ & $\begin{array}{l}\text { UU No. 8/1997 ttg } \\
\text { Dokumen Perusahaan }\end{array}$ & Melengkapi \\
\hline & $\begin{array}{ll}\text { c. } & \text { Bursa - } \\
\text { Perniagaan }\end{array}$ & & & \\
\hline & 1) Pasar Modal & $\begin{array}{l}\text { Buku I Bab IV } \\
\text { Bagian } 2\end{array}$ & $\begin{array}{l}\text { UU No. 8/1995 ttg } \\
\text { Pasar Modal }\end{array}$ & $\begin{array}{l}\text { Kompilasi } \\
\text { Peraturan Pasar } \\
\text { ModaUU No. } \\
\text { 8/1995 ttg Pasar } \\
\text { Modal }\end{array}$ \\
\hline & $\begin{array}{l}\text { 2) Perdagangan } \\
\text { Komoditi }\end{array}$ & $\begin{array}{l}\text { Buku I Bab IV } \\
\text { Bagian } 2\end{array}$ & $\begin{array}{l}\text { UU No. 32/1997 ttg } \\
\text { Perdagangan } \\
\text { Berjangka Komoditi }\end{array}$ & \\
\hline 2 & $\begin{array}{l}\text { Perbankan dan Alat } \\
\text { Pembayaran }\end{array}$ & $\begin{array}{l}\text { Ps. 74-75 KUHD } \\
\text { (Kasir) }\end{array}$ & UU Bank Indonesia & Jauh lebih lengkap \\
\hline 3 & Asuransi & & & \\
\hline & $\begin{array}{l}\text { a. } \text { Asuransi atau } \\
\text { pertanggungan } \\
\text { pada umumnya } \\
\end{array}$ & $\begin{array}{l}\text { Ps. } 246 \text { - Ps. } 286 \\
\text { KUHD }\end{array}$ & $\begin{array}{l}\text { UU No. 2/1992 ttg } \\
\text { Perasuransian }\end{array}$ & Melengkapi \\
\hline & $\begin{array}{l}\text { b. Pertanggungan } \\
\text { Terhadap Bahaya } \\
\text { Kebakaran } \\
\end{array}$ & $\begin{array}{l}\text { Buku I Bag. } \\
\text { Pertama (Ps. } 287 \\
\text { - Ps. 298) } \\
\end{array}$ & $\begin{array}{l}\text { PP No. 73/1992 ttg } \\
\text { Penyelenggaraan } \\
\text { Usaha Perasuransian }\end{array}$ & Melengkapi \\
\hline & $\begin{array}{l}\text { c. } \text { Ttg } \\
\text { pertanggungan } \\
\text { thd bahaya- } \\
\text { bahaya yg } \\
\text { mengancam } \\
\text { hasil-hasil } \\
\text { Pertanian di }\end{array}$ & $\begin{array}{l}\text { Ps. } 299 \text { - Ps. } 301 \\
\text { KUHD }\end{array}$ & $\begin{array}{l}\text { Kitab Undang-Undang } \\
\text { Hukum Perdata }\end{array}$ & melengkapi \\
\hline
\end{tabular}




\begin{tabular}{|c|c|c|c|c|}
\hline & sawah & & & \\
\hline & $\begin{array}{l}\text { d. Pertanggungan } \\
\text { Jiwa }\end{array}$ & $\begin{array}{l}\text { Ps. } 302-308 \\
\text { KUHD }\end{array}$ & $\begin{array}{l}\text { UU. No. 2/1992 ttg } \\
\text { Perasuransian }\end{array}$ & \\
\hline & $\begin{array}{l}\text { e. Pertanggungan } \\
\text { Sosial } \\
\text { Kecelakaan }\end{array}$ & & $\begin{array}{ll}- & \text { UU No. 33/1964 } \\
\text { ttg Sumbangan } \\
\text { Wajib } \\
\text { - } \\
\text { UU No. 34/1964 } \\
\text { ttg Iuran Wajib }\end{array}$ & Diatur tersendiri \\
\hline 4 & $\begin{array}{l}\text { Transportasi dan } \\
\text { Logistik }\end{array}$ & & & \\
\hline & a. Logistik & $\begin{array}{l}\text { Bag. Kedua ttg } \\
\text { Ekspeditur (Ps. } 86 \\
\text { - Ps. } 90 \text { KUHD) }\end{array}$ & $\begin{array}{l}\text { Perpres No. 26/2012 } \\
\text { ttg Cetak Biru } \\
\text { Pengembangan Sistem } \\
\text { Logistik Nasional }\end{array}$ & $\begin{array}{l}\text { Diatur lebih } \\
\text { lengkap dalam } \\
\text { Perpres No. } \\
26 / 2012\end{array}$ \\
\hline & b. Transportasi Laut & Buku Kedua & $\begin{array}{l}\text { UU No. 17/2008 ttg } \\
\text { Pelayaran }\end{array}$ & Melengkapi \\
\hline & $\begin{array}{l}\text { c. Transportasi } \\
\text { Jalan }\end{array}$ & Tidak diatur & $\begin{array}{l}\text { UU No. 22/2009 ttg } \\
\text { Lalu Lintas dan } \\
\text { Angkutan Jalan }\end{array}$ & Diatur tersendiri \\
\hline & $\begin{array}{l}\text { d. Transportasi } \\
\text { Udara }\end{array}$ & Tidak diatur & $\begin{array}{l}\text { UU No. 1/2009 ttg } \\
\text { Penerbangan }\end{array}$ & Diatur tersendiri \\
\hline & $\begin{array}{ll}\text { e. } & \text { Transportasi } \\
\text { Kereta Api }\end{array}$ & Tidak diatur & $\begin{array}{l}\text { UU No. 23/2007 ttg } \\
\text { Perkeretaapian }\end{array}$ & \\
\hline & $\begin{array}{ll}\text { f. } & \text { Transportasi } \\
& \text { Sungai dan } \\
& \text { Penyeberangan }\end{array}$ & Tidak diatur & & Diatur tersendiri \\
\hline & $\begin{array}{ll}\text { g. } & \text { Transportasi } \\
\text { Multimoda }\end{array}$ & Tidak diatur & $\begin{array}{l}\text { Perpres No. 8/2011 ttg } \\
\text { Angkutan Multimoda }\end{array}$ & Diatur tersendiri \\
\hline & $\begin{array}{ll}\text { h. } & \text { Tanggung Jawab } \\
\text { Pengangkutan }\end{array}$ & Tidak diatur & & Diatur tersendiri \\
\hline & $\begin{array}{ll}\text { i. } & \text { Pergudangan }\end{array}$ & & 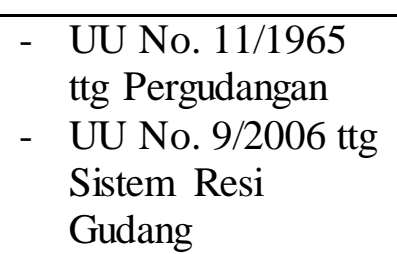 & Diatur tersendiri \\
\hline 5 & Persaingan Usaha & Tidak diatur & $\begin{array}{l}\text { UU No. 5/1999 ttg } \\
\text { Larangan Praktek } \\
\text { Monopoli dan } \\
\text { Persaingan Usaha } \\
\text { Tidak Sehat }\end{array}$ & Diatur tersendiri \\
\hline
\end{tabular}




\begin{tabular}{|c|c|c|c|c|}
\hline \multirow[t]{2}{*}{6} & $\begin{array}{l}\text { Hukum Atas } \\
\text { Kekayaan Intelektual }\end{array}$ & & & \\
\hline & a. Hak Cipta & Tidak diatur & $\begin{array}{l}\text { UU No. 19/2002 ttg } \\
\text { Hak Cipta }\end{array}$ & Diatur tersendiri \\
\hline & b. Paten & Tidak diatur & & Diatur tersendiri \\
\hline & c. Merek & Tidak diatur & & Diatur tersendiri \\
\hline & d. Rahasia Dagang & Tidak diatur & & Diatur tersendiri \\
\hline & e. Design Industri & Tidak diatur & $\begin{array}{l}\text { UU No. } 31 / 2000 \mathrm{ttg} \\
\text { Design Industri }\end{array}$ & Diatur tersendiri \\
\hline 7 & $\begin{array}{l}\text { Perlindungan } \\
\text { Konsumen }\end{array}$ & & $\begin{array}{l}\text { UU No. 8/1999 ttg } \\
\text { Perlindungan } \\
\text { Konsumen }\end{array}$ & \\
\hline 8 & $\begin{array}{l}\text { Pos dan } \\
\text { Telekomunikasi }\end{array}$ & & & Diatur tersendiri \\
\hline 9 & Alat Pembayaran & & & \\
\hline 10 & $\begin{array}{l}\text { Perusahaan Grup } \\
\text { atau Holding } \\
\text { Company }\end{array}$ & Tidak diatur & Belum diatur & $\begin{array}{l}\text { Kerangka } \\
\text { Pengaturan masih } \\
\text { mengikuti Hukum } \\
\text { Perseroan }\end{array}$ \\
\hline
\end{tabular}

Sumber: Rancangan Undang-Undang Tentang Hukum Dagang

Dari tabel diatas menunjukkan persandingan antara KUHD dengan peraturan perundangundangan yang mengatur secara khusus suatu bidang hukum dagang yang secara singkat dapat menggambarkan bahwa memang diperlukan pembaharuan yang lebih spesifik, dalam rangka memperjelas dan mengarahkan ruang-ruang atau batas dalam merumuskan kebijakan kedepannya. Dengan demikian pembaharuan hukum dagang harus melihat kepentingan nasional tanpa mengesampingkan atau malah menutup diri dari dunia internasional. Karna memperjelas makna dan ketentuan dagang/niaga atau bisnis serta perbuatan dagang tersebut lebih diperlukan saat ini mengingat kemajuan teknologi dan revolusi industri 4.0 telah menggeser nilai-nilai dan esensi dari perdagangan itu sendiri. 
Sehingga semakin sulit untuk mengklasifikasikan perbuatan dagang tersebut. Pasar riil dan ekonomi riil secara tak langsung telah di ambil alih oleh dunia maya, karna berdagang era modern tak perlu barang fisik/riil, tak perlu gudang dan tak ada persediaan, hanya menjadi reseller atau agen distribur juga telah dianggap berdagang. Ini juga mengakibatkan pasal tenaga kerja perlahan berkurang dan menghilang ditambah lagi tenaga kerja yang tidak mempunyai kapasitas dan kompetensi akan semakin tertinggal dan terpuruk.

\section{SIMPULAN}

Dalam kehidupan social sudah tentu pasti terjadi perbedaan paham, perang opini, adu argumentasi, bentrok fisik, perebutan hak bahkan banyak pelangaran lainnya. Diperlukan sebuah mediator atau fasilitator untuk mempertemukan dua kepentingan yang bergesekan tersebut, agar tercapai keadilan. Langkah awal ini lah yang dipahami sebagai sebuah proses untuk menuju sebuah sistem (tatanan) hukum. Kondisi tersebut menggiring manusia berpikir secara rasional dalam berbagai kelompok/ komunitas (masyarakat) adat, hal tersebut menjadi pemikiran yang cukup serius. Terbukti kemudian mereka mengangkat pemangku (tetua) adat yang mempunyai kelebihan untuk menjembatani berbagai persoalan tersebut. Kemudian tetua adat yang dipilih dan dipercaya oleh komunitasnya mulai menyusun dan mengatur pola kebijakan sebagai panduan untuk komunitas tersebut yang berisikan larangan, hukuman bagi yang melanggar larangan tersebut, serta bentuk-bentuk perjanjian lain yang sudah disepakati bersama.

Apa yang terjadi di masyarakat adat itulah yang menjadi insprirasi manusia modern untuk melakukan hal serupa. Sesuai dengan perkembangan zaman, masyarakat adat ini pun harus melakukan kontak sosial dengan masyarakat adat lainnya untuk memenuhi kebutuhannya, yang kemudian terjadi tukar menukar kebutuhan pokok. Alat tukar (transaksi) yang kemudian dikenal dengan istilah barter. Masyarakat-masyarakat adat tersebut saling berinteraksi akhirnya mengadakan perjanjian bersama untuk membentuk sebuah ikatan yang lebih luas, yang kemudian dikenal sebagai istilah "Negara". Namun sejatinya Negara ini sebenarnya berisikan berbagai kumpulan hukum adat, yang terkadang saling berbenturan satu sama lainnya. 
Di Indonesia sendiri merupakan Negara hukum sebagaimana dinyatakan dalam konstitusi Indonesia yang dinyatakan dalam Pasal 1 ayat (3) UUD NKRI tahun 1945 yaitu Negara Indonesia adalah Negara hukum (Rechtstaats) bukan Negara kekuasaan (Machtsstaat). Negara yang menjunjung tinggi hukum memiliki tujuan hukum antara lain ketertiban, ketentraman, kedamaian, kesejahteraan dan kebahagiaan dalam tata kehidupan bermasyarakat. Hukum memang dibuat oleh Negara tidak semata-mata menjadi alat perekayasa sosial, tetapi lebih dari itu untuk menegakkan keadilan dan melindungi harkat manusia. Berbagai macam aturan hukum pun telah dibuat untuk mencapai tujuan tersebut, antara lain sebagai berikut.

Hukum dagang ialah hukum yang mengatur yang mengatur tingkah laku manusia yang turut melakukan perdagangan untuk memperoleh keuntungan atau hukum yang mengatur hubungan hukum antara manusia dan badan-badan hukum satu sama lainnya dalam lapangan perdagangan. Menurut Prof. Sudirman Kartohadiprojo, KUHD merupakan suatu lex specialis terhadap Kitab Undang-Undang Hukum Sipil (KUHS) sebagai lex generalis, maka sebagai lex specialis, kalau andaikata dalam KUHD terdapat ketentuan mengenai hal yang dapat aturan pula dalam KHUS, maka ketentuan dalam KUHD itulah yang berlaku.

Hukum pajak adalah himpunan yang mengatur hubungan antara pemerintah dan wajib-wajib pajak antara lain mengatur siapa-siapa dalam hal apa dikenakan pajak (objek pajak). Pajak adalah iuran kepada Negara yang terhitung oleh wajib membayarnya (wajib pajak) berdasarkan undang-undang dan tidak mendapat prestasi (balas jasa) kembali yang langsung. Secara yuridis/ konstitusional; pasal 23A UUD 1945, pajak dan pungutan lain yang bersifat memaksa untuk keperluan Negara diatur dengan undang-undang. Secara sosiologis; pajak sebesar-besanya digunakan untuk kesejahteraan rakyat, dan secara filosofis; pajak untuk menciptakan keadilan sosial.

Hukum perdata (burgerlijkrecht) adalah rangkaian peraturan-peraturan hukum yang mengatur hubungan hukum antara orang yang satu dengan orang yang lain dengan menitikberatkan pada kepentingan perseorangan. Hukum perdata adalah ketentuan dan peraturan yang mengatur dan membatasi kehidupan manusia atau seseorang dalam usaha memenuhi kebutuhan atau kepentingan hidupnya. Hukum pidana adalah hukum yang mengatur tentang pelanggaran-pelanggaran dan kejahatan terhadap kepentingan umum, 
perbuatan mana diancam dengan hukuman yang merupakan suatuu penderitaan atau siksaan.

Hukum administrasi Negara adalah peraturan hukum yang mengatur administrasi, yaitu hubungan antara warga Negara dan pemerintahnya yang menjadi sebab hingga Negara itu berfungsi. Hukum administrasi Negara adalah keseluruhan aturan hukum yang mengatur bagaimana Negara sebagai penguasa menjalankan usaha-usaha untuk memenuhi tugasnya.

Hukum tenaga kerja adalah hukum yang mengatur tentang segala hal yang berhubungan dengan tenaga kerja pada waktu sebelum, selama, dan sesudah kerja. Hukum agraria adalah kaidah-kaidah yang mengatur hubungan antara orang dengan bumi, air, ruang udara, dan kekayaan alam yang terkandung didalamnya. Hukum lingkungan adalah keseluruhan peraturan yang mengatur tingkah laku manusia tentang apa yang seharunya dilakukan atau tidak terhadap lingkungan. Hukum adat adalah hukum yang diidentikkan dengan hukum agama yang dalam bahasa belanda "godsdiens tigeweten" selaras dengan pendapat Van Den Breg yang memperkenalkan teori receptia in complexto, yang menyatakan bahwa hukum adat golongan (hukum) masyarakat merupakan receptie seluruh agama yang dianut masyarakat. Hukum Syara' Islam adalah ajaran Islam yang membicarakan amal manusia baik sebagai makhluk ciptaan Allah mapun hamba Allah.

Itulah kesemua hukum yang ada di Indonesia, sepertinya pemerintah perlu mempertimbangkan asas hukum dam legalitas hukum sebagai acuan perumusan kebijakan dalam upaya membuat roadmap demi kemajuan bangsa Indonesia kedepannya, agar tidak terjadi lagi benturan undang-undang baik dalam bahasa maupun penafsiran. Serta menjadi jembatan dan titik temu dalam menarik benang merah suatu permasalahan atau kebijakan.

Karena Omnibus law merupakan hal baru dalam bidang peraturan perundangundangan Negara Republik Indonesia, selain karena sistem hukum Negara kita menganut Civil Law juga dalam hierarki / tata urutan peraturan perundang-undangan di Indonesia belum memasukkan konsep omnibus law sebagai salah satu asas dalam sumber hukum. Walaupun Undang-Undang yang nantinya dihasilkan dari konsep omnibus law bias mengarah sebagai Undang-Undang Payung karena mengatur secara menyeluruh dan 
kemudian mempunyai kekuata terhadap aturan yang lain. Akan tetapi di Indonesia justru tidak menganut Undang-Undang Payung karena posisi seluruh Undang-Undang adalah sama, sehingga kedudukannya harus diberkan legitimasi dalam Undang-Undang Nomor 12 Tahun 2011 diperlukan amandemen.

Selain itu juga perlu dilakukan inventarisir maslah terkait investasi yang komprehensif dan mendalam. Agar semua aspek yang terkait dengan investasi sudah dipahami sehingga dikemudian hari tidak muncul kebingungan atau bahkan kekosongan hukum karena belum adanya instrument hukum yang mengatur permasalahan tertentu.

\section{REFERENCES}

Adolf, Huala. (2005). Hukum Perdagangan Internasional. Jakarta: PT RajaGrafindo Persada.

Anoraga Pandji, Anoraga. (1995). Perusahaan Multi Nasional dan Penanaman Modal Asing. Jakarta: Pustaka Jaya.

Arifin, Mohammad. (2004). Teori dan Filsafat Hukum: Telaah Kritis Atasi Teori-Teori Hukum (Susunan I) Cetakan Kedua. Jakarat: PT Grafindo Persada.

Asshiddiqie, Jimly. (2010). Perihal Undang-Undang. Jakarta: PT RajaGrafindo Persada.

Badan Pembinaan Hukum Nasional (BPHN). (2013). Naskah Akademik Rancangan Undang-Undang tentang Hukum Dagang. Kementerian Hukum dan HAM RI. Jakarta.

Erwin, Muhammad. (2011). Filsafat Hukum: Refleksi Kritis terhadap Hukum dan Hukum Indonesia (dalam Dimensi Ide dan Aplikasi). Jakarata: PT RajaGrafindo Persada.

Kitab Undang-Undang Dagang (Wetboek van Koophandel voor Indonesie) S.1847-23

Kitab Undang-Undang Hukum Perdata (Wetboek van Koophandel voor Indonesie) S.1847-23 Kitab Undang-Undang Hukum Pidana Kitab Undang-Undang Perpajakan Susunan Dalam Satu Naskah.

Kusumaatmajaya. (1986). Fungsi dan Perkembangan Hukum dalam Pembangunan Nasional. Bandung: Binacipta.

Pramono, Nindyo. (2006). Perkembangan Arus Investasi ditinjau dari Pespektif Hukum Bisnis, Jurnal Legislasi Indonesia, Vol. 3. Jakarta.

Rasjidi, Lili. (1988). Filsafat Hukum. Bandung: CV Remaja Karya.

Siregar, Mahmul. (2007). Undang-Undang Penanaman Modal dan Penyelesaian Sengketa Perdagangan Internasional dalam Kegiatan Penanaman Modal, Jurnal Hukum Bisnis, Vol. 24 Nomor 4, Yayasan Pengembangan Hukum Bisnis, Jakarta.

Sood, Muhammad. (2001). Hukum Perdagangan Internasional. Jakarta: PT Raja Grafindo Persada. 
Wahyudin, A. Teguh. (2019). Konsep Implementasi Onmibus Lawa Pada Sistem Perundang- Undangan. Magister Ilmu Hukum Fakultas Hukum Universitas Semarang.

Zaidun, Muhammad. (2005). Penerapan Prinsip-Prinsip Hukum Internasional Penanaman Modal Asing di Indonesia (Ringkasan Disertasi), Program Pasca Sarjana Univ. Airlangga, Surabaya. 